Journal of Clinical Pathology, 1979, 32, 859-881

\title{
Herpesviruses
}

\author{
MORAG C. TIMBURY ${ }^{1}$ AND ELIZABETH EDMOND 2 \\ From the ${ }^{1}$ Department of Bacteriology, Royal Infirmary, Glasgow and the ${ }^{2}$ Regional Virus Laboratory, \\ City Hospital, Greenbank Drive, Edinburgh, UK
}

Herpesviruses are ubiquitous in both human and animal populations (Plummer, 1967). The four human herpesviruses are herpes simplex (HSV), varicella-zoster (VZ), cytomegalovirus (CMV), and Epstein-Barr (EBV) viruses, and all exhibit the property, rare among human pathogenic viruses, of remaining latent within the body after primary infection. Latent virus persists for many years-probably throughout life - and in some patients reactivates to cause secondary or recurrent infections. Human herpesviruses can almost be regarded as part of the commensal flora, and certainly HSV is present in the saliva of healthy people from time to time (Douglas and Couch, 1970). The viruses exhibit a remarkably successful parasitism since the upset to the host is minimal or, more often, absent. Like all herpesviruses, the four human viruses have identical particles with a striking morphology (Fig. 1). Nevertheless, they differ considerably in biological and pathogenic properties, and it is these that will be described and compared in this review.

\section{Herpes simplex virus}

HSV is the most studied and best understood of the human herpesviruses. Easy to cultivate in cell cultures, it produces a rapid and characteristic cytopathic effect (CPE). There are two types of HSV: type 1 (HSV-1) and type 2 (HSV-2). These differ in their sites of infection since HSV-1 infects head and neck, whereas HSV-2 infects the skin below the waist and most often causes lesions on the genitalia. The difference in site is not absolute, and Smith et al. (1976) have found that $22 \%$ of genital lesions in female patients were due to HSV-1. HSV-2 differs from HSV-1 in several properties although the viruses are genetically very similar (Kieff et al., 1972). HSV-1, for example, grows to higher titre in cell cultures, is more thermostable, and produces a recognisably different CPE to HSV-2 (Plummer et al., 1968; 1970). Despite a considerable degree of cross-neutralisation, the viruses can be distinguished serologically (Schneweis, 1967). Kinetic neutralisa-

Received for publication 15 May 1979 tion (Plummer et al., 1970) or microneutralisation tests (Pauls and Dowdle, 1967) are often used for this, but differentiating the two types of virus today can probably be done more easily by biochemical methods. Thus the DNA of the viruses can be distinguished by restriction enzyme analysis (Skare $e t$ al., 1975). Similarly, many of the virus polypeptides produced in infected cells by the two types of virus can be distinguished by polyacrylamide gel electrophoresis (Courtney and Powell, 1975).

\section{LABORATORY DIAGNOSIS}

HSV-1 infections are most rapidly diagnosed by isolation of the virus in cell cultures such as BHK21 or RK13 cells (Grist et al., 1979). The virus causes a rapid and characteristic $\mathrm{CPE}$, and identification can subsequently be confirmed by neutralisation test. Primary infection can be diagnosed serologically by demonstration of a rising titre or sometimes by high stationary titres of antibody in complement fixation tests. Cross reactions with VZ virus may make interpretation difficult, but neutralisation tests are usually specific (Grist et al., 1978). Recurrent infections do not usually cause either a rise in titre or diagnostically high titres of antibody. If laboratory diagnosis is required, isolation should be attempted.

\section{EPIDEMIOLOGY}

Infection with HSV-1 is virtually universal. The most common route of infection is close personal contact, such as kissing, when virus is transmitted via infected mouth secretions. Infection is usually acquired during the first three years of life, the incidence of antibody rising steadily throughout childhood to show a second peak during adolescence (Smith et al., 1967). Smith and her co-workers found that $84 \%$ of people aged between 30 and 39 years had HSV-1 antibody. HSV-2 is usually sexually transmitted (Astruc, 1754) and is less common than HSV-1. Nevertheless, HSV-2 infection is not rare, and suggestions that it may play a role in cervical cancer have kept interest in this virus at a high level (Naib, 1966; Rawls et al., 1970). The association is not yet proven, but HSV-2 shows oncogenic potential in vitro in that it transforms cultures of rodent embryo 


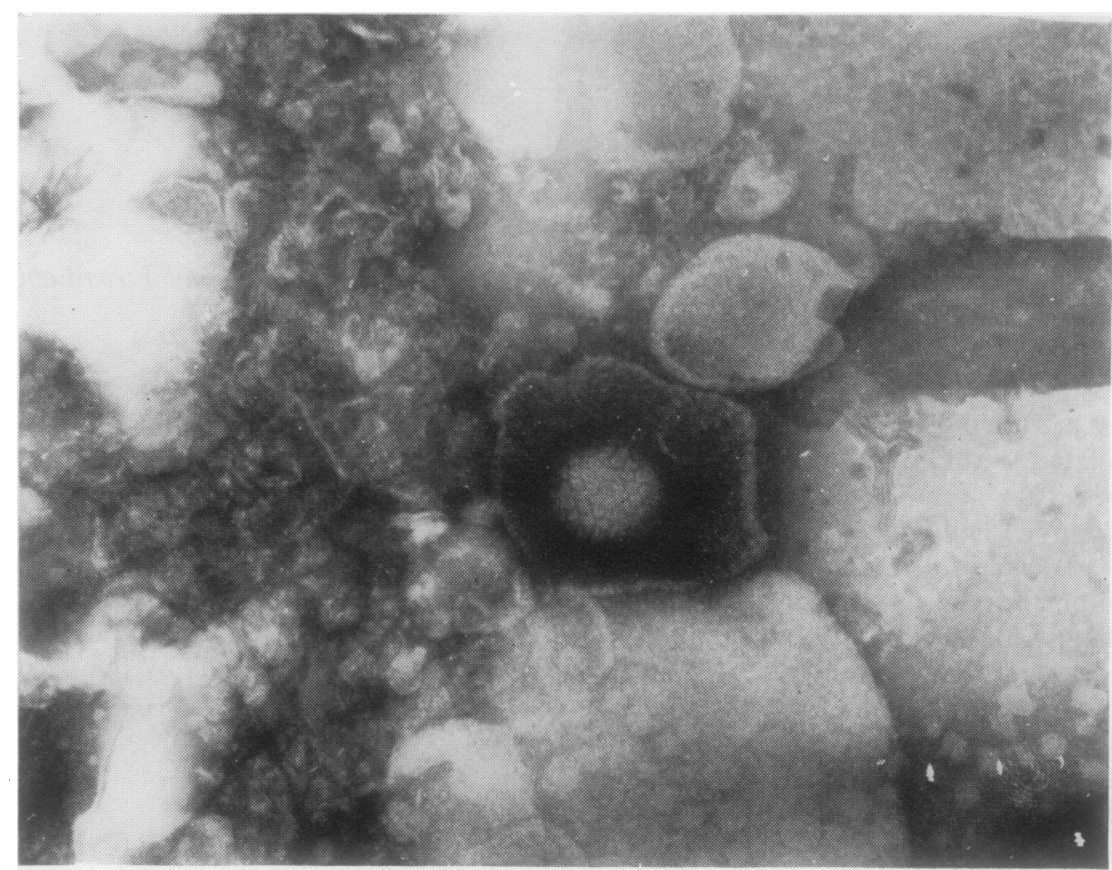

Fig. 1 Herpes simplex virus particle $\times 108$ 000. Photograph by Dr E. A. C. Follett. Reproduced with permission from Notes on Medical Virology by M. C. Timbury, Sixth edition. Churchill Livingstone, 1978.

cells (Duff and Rapp, 1971; Macnab, 1974). A focus of HSV-2 transformed cells is shown in Figure 2.

\section{PRIMARY HSV INFECTIONS}

Primary infections with HSV-1 are usually symptomless, but when disease is produced this most often takes the form of acute gingivostomatitis with painful membranous ulcers in the mouth (Burnei and Williams, 1939). Vesicles are sometimes produced on other areas of the skin, the head or neck being the commonest sites. Sometimes the eye is affected, giving rise to keratoconjunctivitis (Mintz, 1976). Primary herpes can produce a surprisingly large number of different diseases. For example, infection of the finger can mimic a painful whitlow (Adamson, 1909). This is an occupational hazard of anaesthetists and nurses whose fingers may become contaminated with virus-containing throat secretions from patients (Stern et al., 1959). HSV-1 may superinfect eczematous skin to cause Kaposi's varicelliform eruption (Kaposi, 1895; Lynch, 1945), a condition that may be severe with a case fatality rate of up to $50 \%$ (Mintz, 1976). HSV-2, the cause of genital herpes, produces vesicles progressing to ulceration on external genitalia or the anal region. The cervix is probably quite often involved in genital herpes, and Willcox (1968) has described necrotic cervicitis associated with considerable constitutional disturbance. Babies born to mothers with a primary HSV-2 infection late in pregnancy sometimes develop generalised HSV-2 infection (Nahmias et al., 1967). Not all cases of neonatal herpes are due to HSV-2; some are due to HSV-1, and in them the source of infection is 'probably most often a HSV-1 lesion in the mother (Quilligan and Wilson, 1951; Hanshaw and Dudgeon, 1978) or, in one instance, probably the father (Linnemann et al., 1978). Clinically, neonatal herpes is generally a severe disease with a high mortality rate. The infection is disseminated with a vesicular rash and signs of visceral involvement due to hepatoadrenal necrosis (Hass, 1935). Respiratory distress and bleeding are common features, but sometimes signs of CNS disturbance such as convulsions and raised intracranial pressure dominate the clinical picture (Hanshaw and Dudgeon, 1978). Primary infection with HSV-1 can become disseminated in previously healthy adults, but this is very rare (Kipping and Downie, 1948; Juel-Jensen, 1970). Generalised herpes presenting as acute hepatitis in an adult has also been described (Francis et al., 1972).

\section{LATENCY}

Both HSV-1 and HSV-2 become latent in ganglia after primary infection. With HSV-1 this is most 


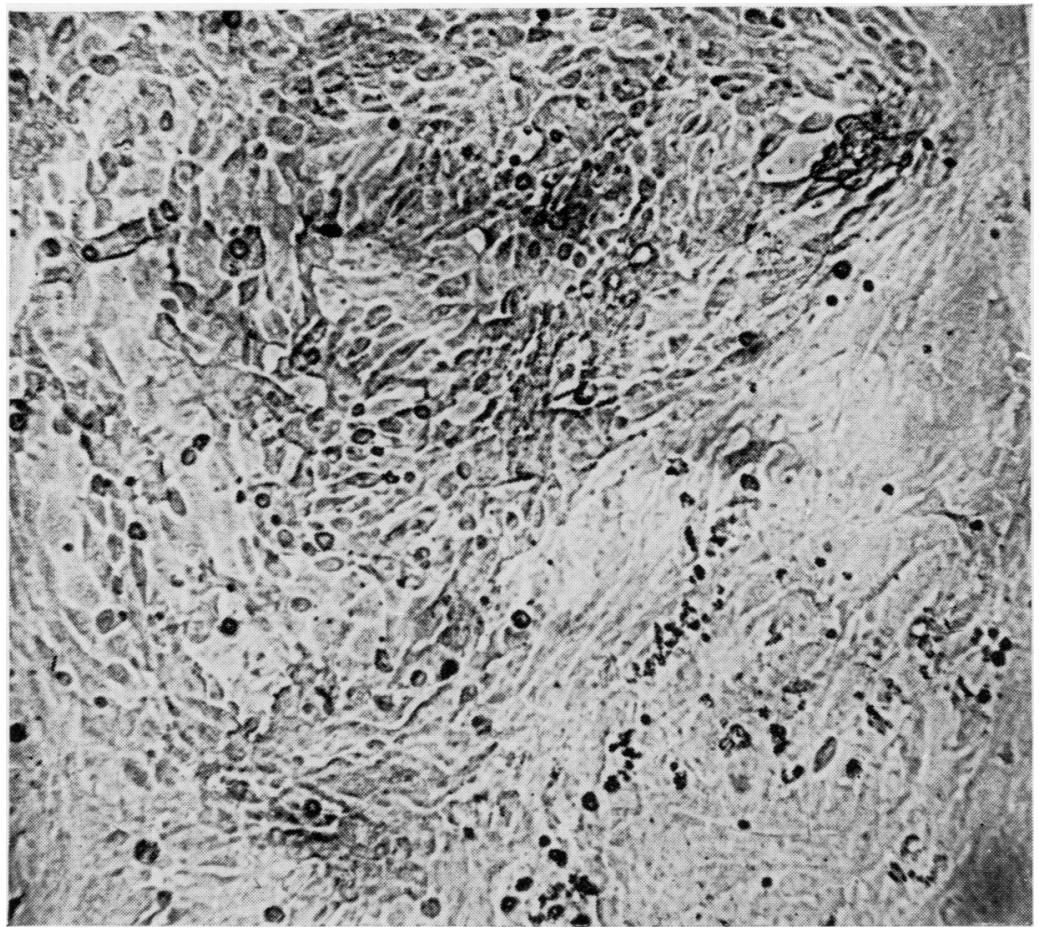

Fig. 2 Focus of rat embryo cells transformed by type 2 herpes simplex virus. Photograph by Dr J. C. Macnab.

often the trigeminal ganglia (Bastian et al., 1972; Baringer and Swoveland, 1973) from which virus can be recovered in $60 \%$ of cadavers by co-cultivation with susceptible cells (Warren et al., 1977). The state of the virus in the ganglia is unknown. To recover virus from ganglia requires prolonged co-cultivation of ganglion explants with susceptible cells; yet HSV is a fast-growing virus which normally produces a rapid CPE in cell culture. This suggests that HSV is not present in ganglia as free infectious virus. It is tempting to speculate that the virus DNA may be integrated into the chromosomes of the neurones or other ganglion cells in the form of a provirus, but there is no evidence at present to support this. The mechanism of reactivation of latent virus and its subsequent neural spread to produce lesions in the appropriate area of skin is also unknown. Recently, latent HSV-1 has also been demonstrated in the superior cervical and vagus ganglia (Warren et al., 1978). Linnemann et al. (1978) have shown that individual strains of HSV-1 can be distinguished by DNA restriction enzyme analysis. This technique has shown that viruses from the same person are identical but differ from virus strains carried by other people (Lonsdale et al., 1979). The sites of latent HSV-2 are the sacral ganglia (Baringer, 1974).
REACTIVATION

HSV-1 reactivations are either symptomless (Douglas and Couch, 1970) or cause the familiar cold sores at mucocutaneous junctions around the mouth and nostrils. Recurrent infection seems to be due to virus reactivation in ganglia with centrifugal spread down sensory nerves to cause lesions in areas of skin supplied by the nerves (Goodpasture, 1929). Recurrent infection sometimes involves the cornea (presumably via the ophthalmic nerve from the trigeminal ganglion) to cause dendritic ulceration with the risk of progressive damage to the eye (Jones, 1958; Norn, 1970). Like HSV-1, HSV-2 infection on the genitalia may become recurrent (Legendre, 1853; Hutfield, 1967; Parker and Banatvala, 1967). The most severe of all herpes diseases is acute necrotising encephalitis (Smith et al., 1941; Olson et al., 1967; Adams and Jennett, 1967). Although the origin of the virus in this disease is uncertain, it is probably more often due to reactivation than to primary infection. The main site of infection is usually the temporal lobes, and the necrosis produced may cause signs and symptoms that mimic those of a space-occupying lesion (Adams and Jennett, 1967). The mortality rate is high, and disabling neurological sequelae are common in survivors. 
INFECTION IN IMMUNOCOMPROMISED

PATIENTS

Patients whose immunological defences are impaired by disease or drugs are unusually susceptible to infection with HSV. This is manifest by the tendency of some of these patients to develop severe lifethreatening infections although many, of course, develop typical herpes in the same way as normal people. The main types of patient susceptible to this form of herpes are those suffering from leukaemia or other forms of cancer and those on immunosuppressive therapy. There is some doubt as to whether immunocompromised patients develop herpes more often than normal people. Aston et al. (1972) found an increased incidence of herpetic infection in patients with myeloproliferative and lymphoproliferative diseases, but no rise in the incidence of herpes was found among renal transplant patients studied by Spencer and Andersen (1970). What is not in doubt is that such patients sometimes develop very severe infections. Abnormally extensive spreading cold sores have been described in renal transplant patients (Montgomerie et al., 1969; Crosby et al., 1969), and, in some, the ulceration had spread to

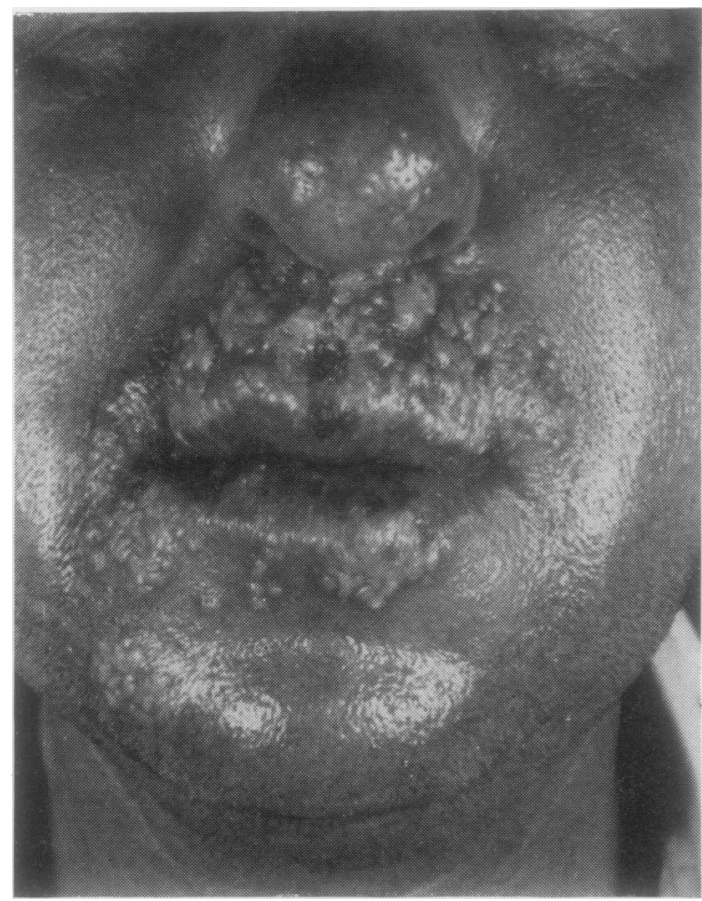

Fig. 3 Extensive cold sores in a patient with a renal transplant. Reproduced, with permission, from Kidney Transplantation; Principles and Practice edited by Professor P. J. Morris. Copyright by Academic Press Inc. (London) Ltd, 1979. involve the oesophagus and gastrointestinal tract (Montgomerie et al., 1969). Similar spread of ulceration to the gastrointestinal tract has been described in a patient with leukaemia (Howiler and Goldberg, 1976). A patient with a renal transplant with extensive cold sores is illustrated in Figure 3. Sometimes herpes in immunocompromised patients becomes an overwhelming generalised infection. This has been reported in children with leukaemia (Ruiz-Palacios et al., 1977; Faden et al., 1977) in whom haemorrhage and necrosis affecting liver, adrenals, gastrointestinal tract, lungs, and brain were found at postmortem examination (Ruiz-Palacios et al., 1977). Fatal disseminated herpes has been described in a large series of severely malnourished children in South Africa (Becker et al., 1963; Kipps et al., 1967), which suggests that malnourishment-and kwashiorkor in particular-enhances susceptibility to this form of herpes. Infection may become disseminated in adults also, and Naraqi et al. (1976) have described viraemia in four adults with pre-existing disease, two of whom had renal transplants. In all four patients the infection was probably due to reactivation since they had antibody before infection, and all recovered. Hepatitis is a constant feature of severe generalised HSV infection in malnourished children and was the predominant and presenting feature in a pregnant patient with hyperemesis gravidarum (Flewett et al., 1969), a case of Hodgkin's disease (Lee and Fortuny, 1972), a renal transplant patient (Anuras and Summers, 1976), and an asthmatic patient on cortisone therapy (Diderholm et al., 1969). Severe herpetic superinfection of burns has been described (Foley et al., 1970), in which two of six patients died from disseminated infection. This condition is reminiscent of Kaposi's varicelliform eruption, and it may be that the latter should more correctly have been included as infection in a compromised patient.

\section{TREA TMENT}

Infections with HSV are among the few viral diseases for which specific treatment is available. However, it must be stressed that antiviral therapy is generally considerably less effective and less free from sideeffects than the use of antibiotics in bacterial disease. The antiviral drugs that are active against HSV are pyrimidine or purine analogues, and three compounds are in current use: idoxuridine (5-iodo-2deoxyuridine), cytarabine (cytosine arabinoside), and vidarabine (adenine arabinoside).

Idoxuridine is widely used for the treatment of herpes keratitis. Applied locally every one or two hours as a $0 \cdot 1 \%$ solution, it clears up the acute disease in most patients. Perhaps not surprisingly, it does not prevent recurrences (Patterson et al., 1963; Ey et al., 1964; Norn, 1970). More recently, a new 
compound, acycloguanosine, has been reported to be effective in producing 'brisk healing' and preventing recurrence-at least within a short period of seven days (Jones et al., 1979). Human interferon is not generally available but it has been tried in herpes keratitis and was also found to prevent recurrences of dendritic ulcer in a short-term follow-up of from seven to 10 days (Jones et al., 1976). Whether these drugs will be effective in preventing recurrence in the long term is unknown. Herpetic skin lesions and whitlows can also be treated with locally applied idoxuridine, but in this instance the drug is applied as a solution of $5 \%$ or $40 \%$ (in the case of whitlows) in dimethyl sulphoxide (Juel-Jensen and MacCallum, 1972). Dimethyl sulphoxide aids penetration of the drug into the skin, and there is evidence that this treatment reduces the duration of pain and hastens healing of lesions (Juel-Jensen and MacCallum, 1972). Verbov (1979) has also found that widespread herpetic skin infection, including Kaposi's varicelliform eruption, responds well to local applications of $5 \%$ idoxuridine in dimethyl sulphoxide. Infections that require systemic treatment present difficult problems. All three drugs act by inhibition of DNA synthesis and all have toxic side-effects, of which the most serious is bone marrow depression; they are administered intravenously. Vidarabine seems less toxic than the other two. Herpes encephalitis was, in the early days of drug therapy, widely treated with idoxuridine. However, although scattered case reports indicated that this treatment might be effective, a collaborative study organised in Boston and reported in 1975 showed that this was not the case. The trial was, in fact, cut short because of unacceptable side-effects and the high death rate in the treated patients. Herpes encephalitis is now treated with intravenous vidarabine, and a controlled trial (Whitley et al., 1977) has clearly shown that this treatment is effective although formidable problems remain with regard to neurological sequelae in survivors. Cytarabine has been used with apparent success in generalised herpes by JuelJensen (1970). It reduces virus shedding and is the preferred drug for this condition.

\section{Varicella-zoster virus}

Varicella-zoster (VZ) virus can also become latent in ganglia after primary infection. It, too, can reactivate, although less often than HSV, and when it does, it causes the characteristic disease, zoster. This consists of vesicles limited to an area of skin corresponding to a dermatome supplied by a sensory nerve from the appropriate posterior root ganglion. VZ virus grows slowly in cell cultures of human embryo lung and thyroid cells with the production of a CPE which starts as foci of rounded cells. The virus is strongly cell-associated and has to be passaged by inoculation of infected cells rather than the culture medium. $\mathrm{VZ}$ virus is extremely labile, and infectivity is rapidly lost at room temperature or by drying.

\section{LABORATORY DIAGNOSIS}

Infections are best diagnosed serologically. A rising titre or high stationary titres of antibody can usually be demonstrated in both varicella and zoster by complement fixation tests in which infected cells are used as antigen. Virus can also be isolated from vesicle fluid, but this is technically considerably more difficult than serology. Typical herpes particles can often be demonstrated in vesicle fluid by electron microscopy, and this can occasionally be a useful method of rapid diagnosis. Morphologically, however, the virus cannot be further diagnosed than as a herpesvirus.

\section{EPIDEMIOLOGY}

$\mathrm{VZ}$ infection is commonly acquired during childhood, but infection is not quite as universal as measles. As a result, a proportion of adults are non-immune. Varicella is acquired by inhalation-usually of respiratory secretions from another case of the disease. However, varicella can also be acquired from contact with cases of zoster, probably due to inhalation of virus shed from skin lesions (Peterson and Black, 1946; Seiler, 1949; Hope Simpson, 1954). Varicella is seasonal, being more common in winter and spring. Zoster is not seasonal and, despite occasional claims to the contrary, is widely accepted as due to reactivation of endogenous virus which has become latent after varicella, usually many years previously.

\section{PRIMARY INFECTION}

Varicella is the result of primary infection with $\mathrm{VZ}$ virus, and, unlike HSV, primary infection is usually accompanied by symptoms. Non-immune adults who acquire infection have a relatively high chance of developing varicella pneumonia (Weinstein and Meade, 1956; Sargent et al., 1967; Carstairs and Emond, 1963). This complication varies in severity from a mild disease, in which pulmonary changes on $x$-ray may be more striking than the clinical condition of the patient suggests, to a severe illness. In the latter group, patients can be very ill with high fever and respiratory distress, and there is sometimes a fatal outcome (Sargent et al., 1967). Varicella pneumonia is often followed by pulmonary calcification (Knyvett, 1966). In children, varicella is generally mild and complications are rare. These can be classified into four categories: respiratory, haemorrhagic, neurological, and infective. The propensity 
for adults to develop varicella pneumonia has been mentioned, but of course children too are not immune from this complication although they are much less likely to develop it. It has long been recognised that there is a haemorrhagic tendency in varicella which is due to thrombocytopaenia. Haemorrhagic syndromes associated with varicella have been reviewed by Charkes (1961). The most common is febrile purpura, in which there is some haemorrhage into vesicles with skin petechiae and occasionally epistaxis and melaena. Post-infectious purpura, which is of later onset, is another recognised complication and, like febrile purpura, is a self-limiting disease with a good prognosis. Rarely, varicella presents, even in previously healthy people, as an overwhelming infection-malignant chickenpox with purpura-in which haemorrhagic manifestations both into the skin vesicles and from internal sites are much more severe (Blair et al., 1965). A very rare complication is gangrenous purpura or purpura fulminans (Gyde and Beales, 1970), in which subcutaneous haemorrhage progresses to gangrene of the extremities, causing shock and sometimes necessitating amputation. This condition and malignant chickenpox with purpura have a high mortality rate.

Like other childhood fevers, varicella is sometimes followed by postinfectious encephalomyelitis although much less often than, for example, measles (Miller et al., 1956). In this form of encephalitis virus cannot be isolated from the brain, and the predominant histological finding is of perivascular infiltration with demyelination. It is, therefore, a totally different disease from the acute necrotising encephalitis due to HSV-1. Cerebellar ataxia is a common feature of varicella encephalitis and has been reported in $37 \%$ of the cases reviewed by Appelbaum et al. (1953). Most patients make a complete recovery from varicella encephalitis although about one-fifth are left with neurological sequelae. Patients who have become comatose have a worse prognosis. A less serious complication of varicella is superinfection of the skin lesions with pyogenic bacteria, but with the advent of antibiotics this now presents little problem in management. Very rarely, the vesicular lesions of varicella become frankly bullous, but this is not associated with severity of infection, and the constitutional disturbance in bullous varicella is mild and the prognosis good (Saslaw et al., 1960). Glomerulonephritis has been reported in association with varicella. Histologically, the renal picture resembles that of poststreptococcal glomerulonephritis (Yuceoglu et al., 1967).

Varicella in pregnancy poses a threat to the infant. In early pregnancy, infection may cause a characteristic syndrome of congenital abnormalities which include limb hypoplasia, muscular atrophy, and cerebral and psychomotor retardation (Laforet and Lynch, 1947; Savage et al., 1973; Hanshaw and Dudgeon, 1978). This condition, however, is exceedingly rare, and only eight cases have been described in the literature over some 25 years (Hanshaw and Dudgeon, 1978). Maternal infection near the time of delivery may spread to the fetus through intrauterine infection and give rise to perinatal or neonatal varicella. The disease can be an overwhelming disseminated infection with necrotic foci in lungs and abdominal viscera and a high mortality rate (Ehrlich et al., 1958; Freud, 1958). Some infants, on the other hand, develop a disease that resembles the normal mild form of childhood varicella (Newman, 1965). The factor that determines the severity of neonatal disease is the time of maternal infection in relation to delivery (Gershon, 1975; Hanshaw and Dudgeon, 1978). If the mother develops varicella five days or more before delivery, then the disease in the infant is mild; if her varicella is within five days of delivery, her child is at risk from severe varicella. The explanation seems to be that varicella at least five days before delivery results in the production of some early maternal antibody which crosses the placenta and modifies the disease in the child. The child therefore develops mild varicella within the first 4 days of life. Maternal varicella nearer the time of delivery is too early for antibody to be produced which might protect her child, and the infant may therefore develop unmodified disease. Infants infected in utero in these circumstances develop varicella between 5 and 10 days after birth, and, in many of them, the disease is severe. The case fatality rate of neonatal varicella acquired as a result of maternal infection within four days of delivery has been estimated to be $30 \%$ (Gershon, 1975).

\section{ZOSTER}

Zoster is mainly a disease of adult life and particularly of the elderly. It is due to reactivation of $\mathrm{VZ}$ virus which has become latent in sensory root ganglia after primary infection, that is, varicella. Presumably the virus gains access to the ganglia during primary infection and, while retaining potential for reactivation, remains latent there throughout life. Clinically, zoster presents a very characteristic picture with a band of painful vesicles-'a belt of roses from Hell' (British Medical Journal, 1979). The lesions are usually restricted to a single dermatome corresponding to the ganglion affected. During an attack, affected ganglia show inflammatory changes with necrosis of nerve cells (Muir, 1976). Virus is presumed to spread down the appropriate sensory nerves to cause lesions in the dermatome supplied by the nerve. Virus can readily be isolated from the vesicles. 
Zoster most often involves dorsal ganglia but zoster affecting lumbar and trigeminal ganglia is common (Hope Simpson, 1965). Rarely, zoster may arise in sacral ganglia with an eruption on the buttocks and genital area and involvement of the bladder (Meyer et al., 1959; Jellinek and Tulloch, 1976). The Ramsey Hunt syndrome-wrongly attributed to geniculate herpes-is characterised by pain in the ear and an eruption on the external auditory meatus, tympanic membrane, and outer ear with facial paralysis. The incidence of zoster rises with age, and in Hope Simpson's practice the annual incidence in octogenarians was $10 \%$ (Hope Simpson, 1965). Recurrent zoster is not infrequentand again elderly patients are more liable to develop this. Neuralgia is a well-recognised and trying sequel, which is particularly common in the elderly (Foster, 1969). Zoster sine herpete may be difficult to diagnose since it manifests as pain within the distribution of the affected nerve without a vesicular eruption (Lewis, 1958). Paralysis not infrequently follows zoster and is more common after cranial (Slatkin and Miller, 1950) than spinal zoster (Gupta et al., 1969). Gupta and his co-workers studied noncranial paralysis and found that, although the majority made a complete recovery, one-sixth had permanent paralysis. Interestingly, paralysis does not always involve muscles in the same segmental distribution as the vesicular eruption although it usually does so (Taterka and O'Sullivan, 1943). Meningoencephalitis has been reported as a complication of zoster. The prognosis is relatively good, and in one series of 14 cases, Appelbaum et al. (1962) found that there were no deaths and, of the nine patients who were followed up, six had no sequelae.

\section{INFECTION IN IMMUNOCOMPROMISED}

PATIENTS

Varicella, the mildest of childhood fevers, can be severe and even lethal in children with leukaemia and, more rarely, other types of cancer (Gordon, 1962; Cheatham et al., 1956). Children on cortisone therapy are also liable to develop severe varicella (Haggerty and Eley, 1956; Nichols, 1957; Finkel, 1961 ; Pinkel, 1961). Varicella in these children shows an unusually extensive and haemorrhagic rash with grave constitutional disturbance, and several of the cases reported in the literature have died. Patients on immunosuppressive therapy for renal transplants have a considerably increased risk of zoster, the incidence in them being recorded as $8 \%$ and $13 \%$ in two different surveys (Rifkind, 1966; Koranda et al., 1974). The risk of developing zoster is particularly high in patients with Hodgkin's disease, in whom Schimpff et al. (1972) and Feldman et al. (1973) reported an incidence of $25 \%$ and $22 \%$ respectively.
Goffinet et al. (1972) found an incidence of zoster in their lymphoma patients of $11 \%$, and of the 129 patients who developed zoster, 21 had disseminated disease. In most of the reported series, a proportion of compromised patients with zoster have suffered from disseminated infection (Merselis et al., 1964; Goffinet et al., 1972; Schimpff et al., 1972). A case of disseminated zoster in a patient with leukaemia is shown in Figure 4. Not surprisingly, this is a serious disease with high fever and considerable malaise, in which pneumonia and encephalomyelitis are frequent complications. The death rate is relatively high, and disseminated zoster worsens the prognosis of the underlying disease. Prolonged and progressive cutaneous zoster has been noted in children with cancer by Feldman and his co-workers (1973).

TREATMENT AND PROPHYLAXIS

Like herpes simplex, some forms of infection with $\mathrm{VZ}$ virus are amenable to antiviral therapy. Since varicella in normal children is generally a mild disease, there is no need to treat it. However, the disease in the immunocompromised child and in some cases of zoster is of such severity or accompanied by such troublesome pain that treatment should

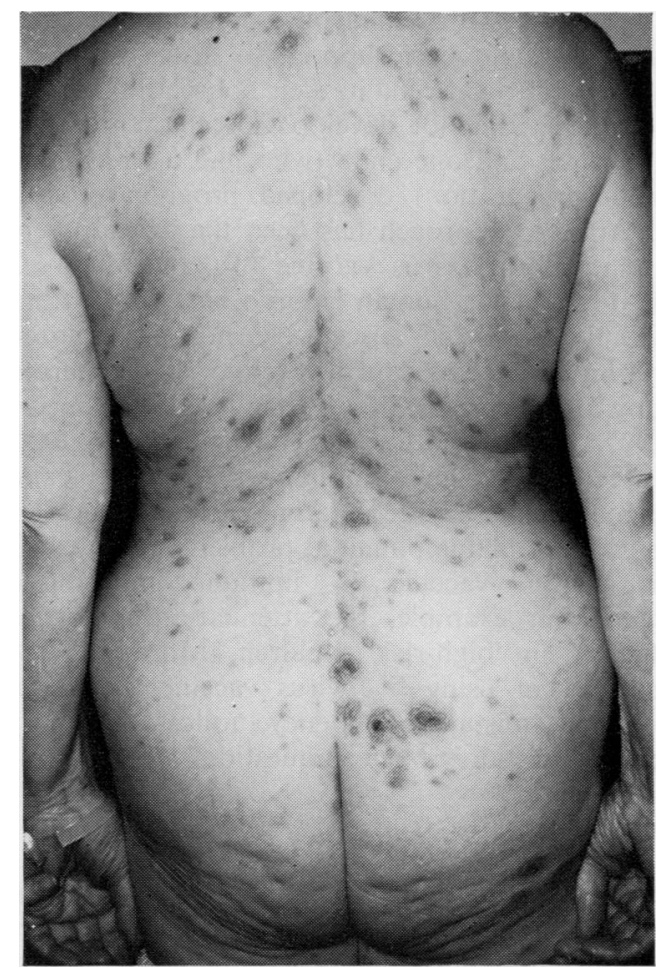

Fig. 4 Desseminated zoster in a patient suffering from chronic leukaemia. Photograph by $\mathrm{Dr}$ A. Lyall. 
be attempted. The drugs used are the same as for herpes simplex. Zoster skin lesions can be treated with locally applied idoxuridine as a $40 \%$ solution in dimethyl sulphoxide, and this has been shown to reduce the duration of pain and to accelerate healing (Juel-Jensen et al., 1970). More recently, Juel-Jensen and MacCallum (1974) have recommended a $35 \%$ solution of the drug in dimethyl sulphoxide. Vidarabine given intravenously is now the drug of choice for the treatment of varicella pneumonia and of disseminated varicella or zoster in immunocompromised patients. It appears to be both effective and relatively free from toxic side effects. Recently, Merigan and his co-workers (1978) have carried out a double-blind trial of human interferon in patients with cancer who were suffering from zoster. Interferon limited the dissemination of lesions and reduced the severity of the pain.

A different approach is immunisation. Brunell and his colleagues in 1969 reported on the results of a controlled trial of zoster immune globulin in healthy susceptible children exposed to varicella from a household contact. The globulin was administered within 72 hours of exposure and none of the treated children developed varicella. Later, Brunell et al. (1972) used zoster immune globulin to protect 'highrisk' children with leukaemia, immunodeficiency disease, or on immunosuppressive drugs who had been exposed to varicella in their household. Five of nine children did not develop varicella, three had mild disease, and one child (who had a less potent globulin preparation) developed progressive varicella. Another approach has been the development of an attenuated virus vaccine (Takahashi et al., 1974). Prepared in human embryo lung cells, it has apparently protected susceptible normal children after household exposure and children on steroid therapy after exposure in a hospital ward (Asano et al., 1977a, 1977b). Hattori and colleagues (1976) have also used this vaccine in children with leukaemia and other malignancies with apparent success. However, there are formidable potential problems when using a live virus vaccine in immunocompromised children. For example, the attenuation might be insufficient in 'high-risk' children. Moreover, the advisability of using live virus vaccines when, in normal circumstances, latency follows primary infection is certainly open to question.

\section{Cytomegalovirus}

Cytomegaloviruses are morphologically typical herpesviruses and form a group of species specific agents infecting many species of mammals and man. As with other herpesviruses, primary infection is followed by life-long persistence of latent virus.
LABORATORY DIAGNOSIS

Histological evidence of infection with human CMV had been recognised many years before human CMV was first isolated from a human fetus in 1956 (Smith, 1956). In vitro the characteristic cytopathology of human CMV (Fig. 5) is seen predominantly in human fibroblasts and consists of focal cytomegalia with the formation of intranuclear and intracytoplasmic inclusions. New isolates of virus from clinical material are largely cell-associated, but high-titre extracellular virus can be produced after laboratory adaptation. Several well-established laboratory strains, such as AD169, Davis, and Ken, are used extensively for the production of antigens for serological tests. Antigenic diversity has been noted regularly between strains of CMV, but in crossneutralisation tests there is a major degree of overlap (Zablotney et al., 1978). Differentiation into types, according to geographic area or site of isolation, is clearly not justified. CMV does not survive well outside the body. Early inoculation of fresh material into cell culture is recommended for isolation from clinical material. If freezing of specimens is unavoidable specimens should be collected into a medium containing sorbitol (Beynesh-Melnick, 1969). Although limited replication takes place in epithelial cells (Knowles, 1976), human fibroblasts remain the cell of choice for primary isolation. Because of the very slow growth of some isolates, cell culture should be maintained for a minimum of one month.

The complement fixation (CF) test is the most widely used method of detecting antibody to CMV. The sensitivity of the test depends on the type of antigen used, glycine extraction increasing sensitivity (Kettering et al., 1977b). For the detection of previous exposure to the virus an indirect immunofluorescence test for antibody to late antigen is most sensitive but introduces the problem of false-positive results due to IgG receptors on infected cells (Keller et al., 1976). The use of an anticomplement fluorescence test (Kettering et al., 1977a) or of isolated nuclei as antigen in the standard test (Stagno et al., 1978) may obviate this difficulty. Long-lasting antibody to CMV has also been detected by an indirect haemagglutination technique (Bernstein and Stewart, 1971) and by microneutralisation (Chiba et al., 1972). Both methods are sensitive and specific but difficult to standardise for routine use. Virus specific IgM antibody detected by indirect immunofluorescence (Hanshaw et al., 1968) is transitory and is a reliable indicator of recent infection if secondary staining due to antiglobulin factors is excluded (Shirodaria et al., 1973). Antibody to early antigen appears to be due more to virus excretion, whether this is related to primary infection or to reactivation (Thé et al., 1974; Gerna et al., 1978). 


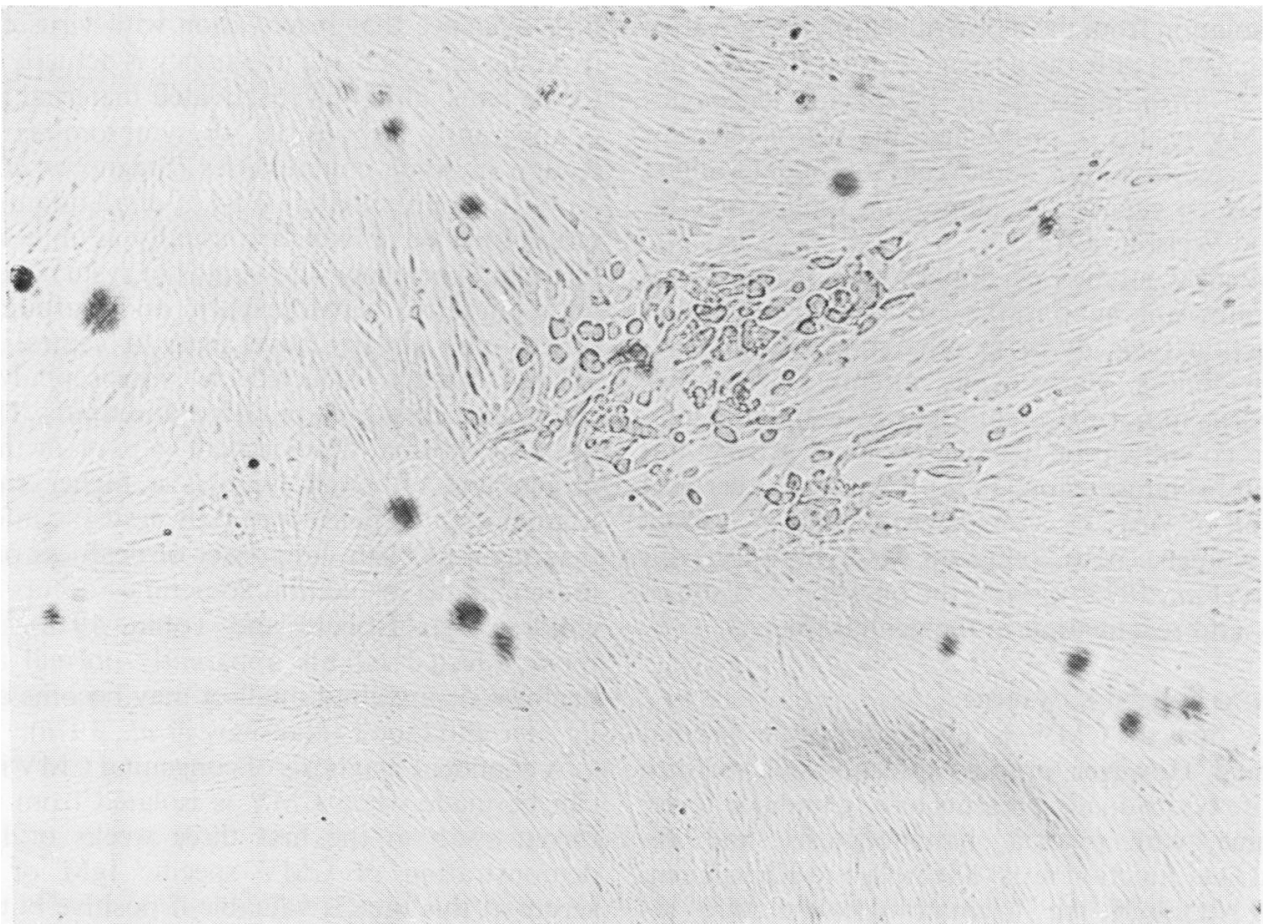

Fig. 5 Cytopathic effect of human cytomegalovirus in human embryo lung cells. Photograph by $\operatorname{Dr} T$. Mills, Glaxo Laboratories.

\section{EPIDEMIOLOGY}

CMV has been isolated from urine, nasopharyngeal secretions, saliva, breast milk, cervical secretions, and semen, any of which may contribute to the horizontal spread of the virus.

Infection may occur during or soon after birth in spite of the presence of passively acquired maternal antibody (Reynolds et al., 1978). The prevalence of antibody in a community increases with age, but the rate of acquisition of antibody is profoundly influenced by socioeconomic conditions. Thus in India $80 \%$ of children have antibody at the age of 4 years (Mukundan et al., 1977), whereas in large cities of more affluent nations only $30-40 \%$ of preschool children have antibody (reviewed by Plummer (1973)). Prevalence rates of CF antibody in adults vary from $40 \%$ in highly industrialised nations to $100 \%$ in underdeveloped countries while high infection rates are also found in underprivileged communities of affluent societies (Krech, 1973).

Natural routes of transmission in the healthy population have not yet been clearly defined although close and prolonged contact is probably required. Unusually high rates of infection have been noted in children living in boarding schools or institutions (Stern and Elek, 1965).
Primary infection with CMV results in prolonged excretion of virus, particularly in childhood when virus excretion may continue for two to three years after postnatal infection. In this country, peak virus excretion rates are found in infants aged 6 months to 4 years (Stern, 1968). Excretion is unusual in normal older children and adults although cervical excretion by sexually active women appears to be more common (Willmott, 1975), providing a source for both horizontal spread of infection to sexual partners and vertical spread of infection to offspring at delivery.

\section{LATENCY AND REACTIVATION}

The sites of CMV latency after primary infection remain undetermined. Three sites are suggested by information presently available. Thus transmission of CMV by blood transfusion to produce the 'post perfusion syndrome' (Kääriänen et al., 1966) in patients undergoing open-heart surgery provides evidence for persistence of virus in some form in the blood, as does the regular seroconversion and virus excretion that follows neonatal transfusion (Yeager, 1974; Tobin et al., 1975). While viraemia can be demonstrated in patients with active infection (Fiala et al., 1975; Lang and Noren, 1968; Jordan et al., 
1973) isolation from the blood of healthy seropositive individuals has only once been reported (Diosi et al., 1969). In vitro infection of peripheral leucocytes with CMV results in prolonged survival of infective virus, suggesting that some cells of undetermined type may be capable of supporting replication (St. Jeor and Weisser, 1977).

Serological studies of donors and recipients of renal transplants support the concept of transmission of infection (vide infra) in renal tissue from seropositive donors. Nevertheless, attempts to demonstrate virus in normal renal tissue by standard isolation or co-cultivation techniques have proved unsuccessful (Naraqi et al., 1978). Finally, the cervical excretion of virus by a small proportion of normal adult women, both pregnant and non-pregnant (Stagno et al., 1975b), raises the question of a site of latency and reactivation in the genital tract.

CLINICAL PRESENTATION

Disease due to CMV is unusual in the normal individual. However, primary infection delayed into adult life occasionally presents as a 'glandular fever' syndrome, with pyrexia, lymphocytosis, and abnormal liver function tests (Klemola and Kääriäinen, 1965). Although the haematological picture resembles that of infectious mononucleosis and a variety of autoantibodies (Kantor et al., 1970) may be produced, the Paul Bunnell test remains negative throughout the course of the disease. The clinical course is usually that of a mild non-specific febrile illness without tonsillitis, lymphadenopathy, or jaundice, but severe complications may arise. The most frequently reported of these is a peripheral neuritis of the Guillain Barré type (Arnold et al., 1978). Frank hepatitis (Lamb and Stern, 1966), myocarditis (Tiula and Leinikki, 1972), chorioretinitis (Chawla et al., 1976), and vasculitis (Bamji and Salisbury, 1978) have been reported in association with CMV infection in previously normal individuals.

The diagnosis of CMV infection can be confirmed in suspected cases by isolating virus from the throat swab or urine and by demonstrating the presence of CMV specific IgM in serum. A rising titre of complement fixing antibody to the virus during the course of the disease may be detected but is often missed if the patient presents late in the course of the infection.

\section{CONGENITAL INFECTION}

Primary infection during pregnancy is recognised as a significant cause of congenital abnormality involving particularly the central nervous system (Hanshaw, 1971). Infection as shown by seroconversion occurs in $3 \%$ of white women in London, and about half of these infected pregnancies result in fetal infection (Stern and Tucker, 1973). There is little evidence that reactivation with virus excretion from the cervix during pregnancy is actually harmful to the fetus, although reactivated maternal infection is apparently responsible for symptomless fetal infection in some communities (Stagno et al., 1977). At birth, approximately $0 \cdot 5-1 \%$ of all infants excrete virus. Infected infants are usually asymptomatic at birth, but some may show signs of systemic infection with jaundice, hepatomegaly, and purpura, while others may already have signs of central nervous system damage reflected in microcephaly, intracerebral calcification, or choroidoretinitis. The prognosis for normal development is poor in this latter group, and although there is a higher chance of normal development when only systemic infection is diagnosed at birth, late onset of deafness or neuromuscular incoordination sometimes occurs in these children (MacDonald and Tobin, 1978). Even in those infected infants apparently normal at birth, deafness or impaired intellect may become apparent in later childhood (Hanshaw et al., 1976).

A confident diagnosis of congenital CMV infection can be made when CMV is isolated from urine or throat swab in the first three weeks of life. The demonstration of CMV specific IgM or IgA in serum at this time is valuable if positive but may be negative when virus excretion is present (MacDonald and Tobin, 1978; Melish and Hanshaw, 1973). The titre of IgG antibody to the early antigen of CMV may be a more sensitive test for congenital infection (Stagno et al., 1975a; Gerna et al., 1978).

Additional support for the diagnosis is the finding of CMV specific macroglobulin in maternal serum. Persistence of CF antibody in the infant is not a reliable indicator of congenital infection as the titre may become negative in infants who excrete virus at birth. Persistence of IgG fluorescence antibody is more sensitive (Stagno et al., 1975a; MacDonald and Tobin, 1978). Even with serial assessment of antibody levels it may be very difficult to discriminate between congenital and perinatal infection.

INFECTION IN THE IMMUNOCOMPROMISED HOST

CMV infection is a regular feature of immunosuppression, whether the immune defect is induced by drugs or invoked by disease. Infection with CMV has been reported after renal, bone marrow, cardiac, and hepatic allografts.

The infection has been extensively studied in recipients of renal transplants in whom the incidence of CMV infection is higher than in any other group of compromised hosts. The rate of urinary virus excretion in these patients varies from 50\% to $95 \%$ (Craighead et al., 1967; Fiala et al., 1975; Spencer, 1974), and although symptomatic infection occurs 
much less frequently there is no doubt that CMV infection contributes to both morbidity and mortality. The discrepancy between the high rate of virus excretion and the much lower rate of symptoms attributable to CMV after renal transplant has been explained by the appreciation of the difference between primary and secondary infection in this situation. Primary infection, which is usually symptomatic, occurs in individuals who are without antibody at the time of transplant and who receive a kidney from a seropositive individual (Ho et al., 1975; Betts et al., 1975). The transplanted organ presumably carries latent CMV infection (although this has been difficult to demonstrate in vitro), which produces disease in the non-immune host after a latent period of one to two months. Symptoms occur in $90 \%$ of primary infections. Prolonged fever, pneumonia, leucopenia, and hepatitis are the most frequent manifestations (Betts et al., 1977).

Reactivation of latent CMV infection occurs in virtually all renal transplant patients who possess antibody before transplant, but these patients generally remain asymptomatic. Virus shedding begins usually in the first three months after transplant and persists for months or years. Reactivated infection probably also accounts for the high rate of virus excretion in adults with neoplasia (Duvall et $a l ., 1966)$ and in patients treated with cytotoxic drugs for rheumatic disorders (Dowling et al., 1976).

CMV infection in transplant recipients is frequently associated with superinfection by other organisms. This increased susceptibility to superinfection in patients undergoing CMV infections has been noted particularly after cardiac transplant (Rand et al., 1978). Two suggested contributory factors to explain such increased susceptibility are local tissue damage occurring during viral replication and additional immunosuppression induced by the virus infection.

In renal transplant recipients, reduced graft survival has been noted in patients with CMV infection (Lopez et al., 1974; May et al., 1978). Similarly, graft versus host disease is seen in association with pneumonitis in recipients of marrow allografts (Meyers et al., 1975).

There may well be two quite different mechanisms of interaction between HLA antigens and CMV infection, either or both of which may play a part in rejection episodes. Thus the production of virus antigens on the surface of transplanted tissue cells during a spreading lytic infection would provide an immunological stimulus additional to that provoked by foreign tissue antigens already present on the graft. On the other hand, there is experimental evidence to suggest that the host versus graft reaction may enhance the reactivation of latent CMV (Olding et al., 1975). The relative importance of these interactions in rejection episodes requires further study.

\section{ONCOGENESIS}

In common with known oncogenic DNA viruses, CMV can induce host-cell DNA and RNA synthesis. Human cells infected with human CMV will grow in soft agar for several generations, exhibiting loss of contact inhibition, although this behaviour is transient and is always followed by lysis of the cells (Lang et al., 1974). A strain of CMV inactivated by ultraviolet light produced transformation in hamster embryo fibroblasts, and these cells are oncogenic in newborn hamsters producing fibrosarcomas (Albrecht and Rapp, 1973). In addition, evidence has recently been presented suggesting that CMV may be involved in adenocarcinoma of the colon (Huang and Roche, 1978). This information is particularly interesting in view of previous reports of CMV infection associated with ulcerative colitis and intestinal ulceration (Cooper et al., 1977).

THERAPY AND PREVENTION

Although limited success in virus suppression has been reported after treatment with both DNA analogues and interferon (Ch'ien et al., 1974; Emödi et al., 1976), the side effects of both types of treatment restrict their exploitation in the circumstances in which they are most urgently required, that is, in infection in the immunosuppressed patient and in congenital infection. Infection in transplant patients can be reduced by screening with sensitive techniques both donor and recipient to prevent, as far as possible, transmission of latent infection from a seropositive donor to a seronegative recipient. Prevention of symptomatic primary infections in both situations may be achieved by the use of a safe and reliable vaccine for seronegative patients before transplant and for seronegative girls before pregnancy. The results of clinical vaccine trials with two candidate vaccines have been published (Elek and Stern, 1974; Plotkin et al., 1976). Both vaccines produced seroconversion in seronegative individuals without side effects other than local reactions.

The important potential risks of using a live CMV vaccine are the suspicion of oncogenicity and the possibility of disease associated with reactivated infection. These problems have had to be considered very carefully before the vaccine has been more widely used. Nevertheless live attenuated herpes vaccines have been used for many years in domestic animals and have proved to be both safe and efficacious. The results of present vaccine trials being carried out in transplant patients in both America and England are awaited with great interest. 


\section{Epstein-Barr virus}

Epstein-Barr virus (EBV), the most recently recognised of the human herpesviruses, was first observed during studies on the ultrastructure of cells originating from a Burkitt lymphoma biopsy specimen (Epstein et al., 1964). There is now no doubt that this virus is the aetiological agent of infectious mononucleosis and that it is intimately associated with Burkitt's lymphoma and nasopharyngeal carcinoma.

\section{LABORATORY METHODS}

The biological activity of EBV can be demonstrated in vitro only by its effect on human or primate $B$ lymphocytes (Pattengale et al., 1973; Jondal and Klein, 1973) which are, as a result of infection with the virus, transformed into continuous lymphoblastoid cell lines (CLC). Such immortalised cells can be initiated from peripheral blood leucocytes of patients with infectious mononucleosis and from any individual who has antibody to EBV, without the addition of extraneous EBV (Nilsson, 1971). The mechanism of production of CLC in these situations is different from that operating when cell lines are initiated from biopsy specimens of Burkitt's lymphoma tumours (Epstein and Achong, 1977). Nevertheless, lines initiated from these sources are composed of B cells, virtually all of which contain EBV genome (Zur Hausen and Schulte-Holthausen, 1970), which is expressed to a variable but characteristic degree in each cell line. Some socalled "non producer' cell lines produce only a nuclear virus determined antigen (EBNA), while in 'producer' lines, a proportion of cells allow complete expression of viral genetic material with the production of a range of viral antigens and free infectious virus. Lymphoblastoid cell lines provide a very convenient in vitro model for both viral transformation and herpesvirus latency which have been intensively studied by a wide variety of techniques employed by a range of scientific disciplines. It has been shown that in the transformed cells the viral DNA exists both in a form integrated with the host chromosomes and in plasmid form (Nonoyama and Pagano, 1972). Regulatory mechanisms in the expression of viral DNA are currently being studied by cell hybridisation techniques in which the expression of viral antigens is traced in heterokaryons formed by fusion of EBV genome-carrying cells either to each other or to genome-negative cells of various types (Glaser and Rapp, 1975; Klein et al., 1976a).

Viral antigens expressed in CLCs have almost all been recognised in tests of immunofluorescence using human serum from patients with Burkitt's lymphoma or with infectious mononucleosis. Antibody profiles to a range of EBV antigens have been defined in detail for both of these conditions and for nasopharyngeal carcinoma. In the acute infection there is an early appearance of IgG antibody (Evans et al., 1968) and IgM antibody (Banatvala et al., 1972 ) to virus capsid antigen (VCA) with, in $80 \%$ of patients, an IgG antibody to one component of the early antigen (EA) complex of EBV (Henle et al., 1971b). A positive indirect immunofluorescent test for IgG antibody to VCA is shown in Figure 6. IgM antibody and antibody to EA are transient, lasting for only a few months after infection, while IgG persists for life. Neutralising antibody (Hewetson et al., 1973) and antibody to EBNA (Henle et al., 1974b) develop more slowly after infection and persist indefinitely. In patients with Burkitt's lymphoma or nasopharyngeal carcinoma the titres to certain antigens are of prognostic significance (Henle et al., 1971a; Chan et al., 1977).

Although the virus cannot be demonstrated readily in nasopharyngeal secretions, its presence in them can be deduced by the in vitro transformation of cord blood lymphocytes. Virus excretion can be shown to occur in $80 \%$ of cases of infectious mononucleosis (Miller et al., 1973) as well as in approximately $20 \%$ of normal healthy seropositive individuals in western communities (Gerber et al., 1972). Excretion rates are higher in patients who are immunosuppressed, whether by drugs or disease, suggesting reactivation of latent virus (Chang et al., 1973; Strauch et al., 1974). There is a surprisingly high $(45 \%)$ excretion rate of virus in apparently normal individuals in areas in which Burkitt lymphoma occurs (Gerber et al., 1976).

\section{EPIDEMIOLOGY}

Healthy excreters in the community provide a source of virus for horizontal transmission. The age incidence of IgG antibody to VCA varies from one community to another, infection occurring at an earlier age in underdeveloped countries or in socially deprived groups of more industrialised communities (Pereira et al., 1969; Biggar et al., 1978; Niederman et al., 1970). Infection in childhood is usually symptomless (Henle and Henle, 1970), and infectious mononucleosis is a problem only in those areas where a proportion of young adults, having escaped earlier infection, meet EBV for the first time. In this country approximately $60 \%$ of new university students are without antibody, and of those, approximately $20 \%$ per year experience infection demonstrable by seroconversion (University Health Physicians and PHLS Laboratories, 1971). Classical infectious mononucleosis occurs in about half of the infected students, the remainder developing either mild symptoms or remaining symptomfree. The reasons for the striking difference in age distribution 


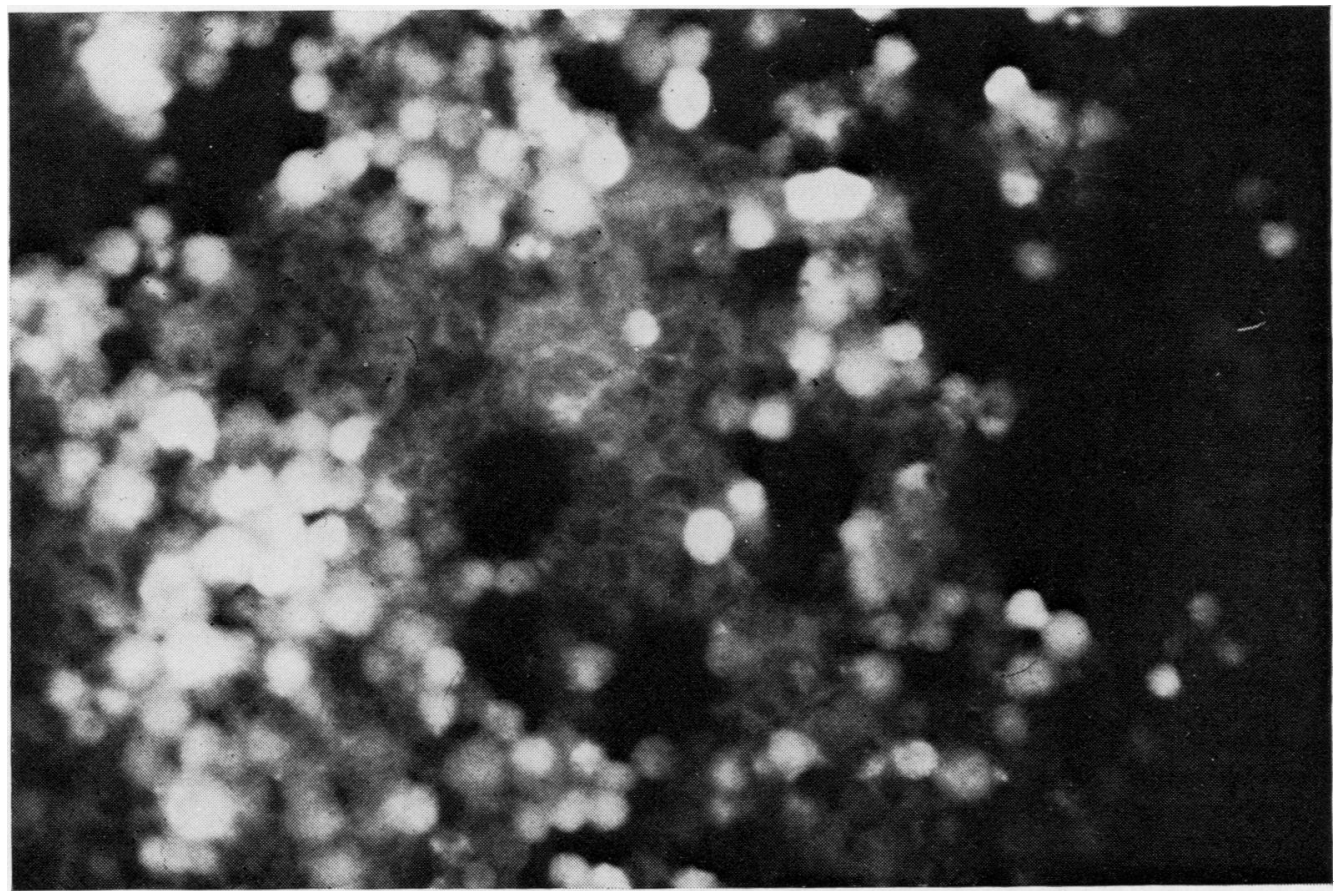

Fig. 6 Positive indirect immunofluorescence test for IgG antibody to EBV viral capsid antigen in EB3 cells.

of asymptomatic infection and disease are unknown, but a large and direct virus inoculum acquired in the so-called 'kissing disease', or the state of maturity of the immunological system, may play a part (Epstein and Achong, 1977).

\section{PATHOGENESIS OF INFECTIOUS} MONONUCLEOSIS

The protean clinical and immunopathological features of infectious mononucleosis (IM) have been well recorded previously (Finch, 1969; Lancet, 1973). In recent years investigation has been directed to unravelling the pathogenesis of this fascinating disease. Although a clearer picture is now emerging, some aspects of the disease have to date eluded satisfactory explanation, and the mechanism of their pathogenesis remains highly controversial. The majority of 'atypical cells' present in the peripheral blood in IM are in fact T lymphocytes (Sheldon et al., 1973). These T cells are cytotoxic to B lymphocytes, expressing a lymphocyte detected membrane antigen (LYDMA) which appears early after infection of B cells with EBV (Rickinson et al., 1977). Presumably the brisk response of the $T$ cells along with the specific EBV antibody response brings to an end the acute infection, but $T$ cells capable of recognising and responding to $B$ cells expressing LYDMA persist probably permanently thereafter (Moss et al., 1978), as do neutralising antibody and antibody to VCA and EBNA. The nature of the virus infection of B cells in vivo has been highly controversial. Are they already transformed by the virus (Klein, 1975); are they in the early stages of virus replication (Ernberg et al., 1976); or are they latently infected with virus (Epstein and Achong, 1977) ? Cells positive for EBNA antigen have been detected in the peripheral blood only rarely in the acute phase of the illness (Klein et al., 1976b). Detailed investigation of a fatal case of IM (Crawford et al.,1979) supports the view that these EBNA positive cells are associated with replicating virus. However, it appears that the EBV genome is also carried in small unstimulated EBNA negative lymphocytes during IM (Crawford et al., 1978), suggesting that latent infection of cells is also present in the acute disease.

The differential Paul-Bunnell-Davidsohn test has been used for 40 years as an apparently 'specific' diagnostic test for IM but an explanation of its close association with the disease remains elusive. Paul Bunnell antigen has been demonstrated in normal (Lowenthal et al., 1973) and pathological (Kano et al., 1977) human tissues and appears to be present on primate cells transformed in vitro by EBV (Shope and Miller, 1973). The antibody is quite distinct 
from antibodies to EBV antigens (Henle et al., 1974a), which acquire particular diagnostic significance in the small proportion of cases in which Paul Bunnell antibody does not develop (Nikoskelainen et al., 1974).

Viral infection of B cells themselves may account for the production of inappropriate antibody such as anti-i, rheumatoid factor, and antinuclear antibody which may appear transiently during the course of IM. Alternatively, such antibody may be produced by noninfected cells released from normal control mechanisms as a consequence of the immunosuppressive nature of EBV infection.

Thus, in the pathogenesis of the acute infection, viral infection of antibody-producing cells is a dominant feature. However, since infective virus is excreted in nasopharyngeal secretions both during the acute infection and afterwards, the existence in the nasopharynx of an additional cell type permissive for EBV replication has been proposed (Miller, 1975; Epstein and Achong, 1977).

In clinical practice, EBV serology is not usually necessary to confirm the classical presentation of IM in which lymphocytosis with atypical lymphocytes and a positive Paul-Bunnell-Davidsohn test are demonstrated. However, the full differential test is not always readily available, and alternative rapid tests are not totally reliable. As previously noted, a small proportion of patients with primary EBV infection do not develop heterophile antibody. In addition, patients with primary EBV infection may not present at the usual age or may not present the classical symptoms of IM. In all of these situations demonstration of IgM antibody to EBV can be a valuable diagnostic procedure, provided due care is taken in performing the test to ensure specificity. IgG antibody titres are not useful diagnostically except in a small number of cases in which the production of EBV antibody is slow and a clear seroconversion or rise in the IgG VCA test can be demonstrated (Blake et al., 1976).

\section{LATENCY AND REACTIVATION}

In the normal individual, IM is always self-limiting, but after infection EBV persists in the blood in spite of the presence of specific cellular and humoral immunity. The evidence for this is the ability of peripheral leucocytes from seropositive adults regularly to produce continuous cell lines in vitro, and the observation that EBV infection may be transmitted by blood transfusion (Gerber et al., 1969). Whether excretion of virus in the $18 \%$ of normal adults is due to reactivated or persistent infection is unknown, but the increased incidence of nasopharyngeal excretion by immunocompromised patients suggests that reactivation can occur.
INFECTION IN THE IMMUNOCOMPROMISED

HOST

Such reactivated infection occurs three to 12 months after tissue transplant, thus strengthening the opinion that it is a result of the immunosuppressive treatment in these patients. A high excretion rate in leukaemia is more closely associated with the disease process and is reduced after the onset of remission (Chang et al., 1978).

Excretion of EBV in the renal transplant recipient is generally asymptomatic, although changes in EBV VCA titre have been associated with febrile episodes (Spencer and Andersen, 1972).

Confirmed primary infections with EBV after transplant procedures have been reported rarely, presumably because many transplant patients have had previous natural and asymptomatic infection. Graft versus host disease was reported in one young marrow transplant recipient who received a marrow graft from a sibling in whom IM had been diagnosed a short time before the transplant procedure. Antibody levels in the recipient followed a course characteristic of primary infection, indicating a normal response to infection by the recipient's own cells (Sullivan et al., 1978). Fever and pneumonitis were the predominant features of primary EBV infection occurring in a young renal transplant recipient (Grose et al., 1977). Thus, both as regards symptomatology and interrelationship with tissue antigens, EBV infection in these circumstances may parallel the behaviour of the more familiar CMV infection.

Primary infection with EBV in conditions of naturally acquired immunodeficiency may result in fatal or prolonged IM. Fatal EBV infections in several male members of individual families have been reported in a genetically determined combined humoral and $\mathrm{T}$ cell immunodeficiency (Bar et al., 1974; Purtilo et al., 1975, 1978). Primary EBV infection in affected males is not always immediately fatal and may be followed later by variable expression of B cell dysfunction or neoplasia (Purtilo et al., 1978). When infection associated with the combined deficiency syndrome is fatal in the acute phase, no EBV antibody can be detected. However, fatal infection has also been described when the appearance of specific EBV antibody suggests an adequate humoral immune response (Crawford et al., 1979).

RELATIONSHIP TO BURKITT'S LYMPHOMA

AND NASOPHARYNGEAL CARCINOMA

A depressed level of cellular immunity, possibly as a result of malarial infection (Dalldorf et al., 1964), has been proposed as a cofactor with EBV infection in the production of endemic African Burkitt's lymphoma (Fig. 7). In endemic areas, infection with 


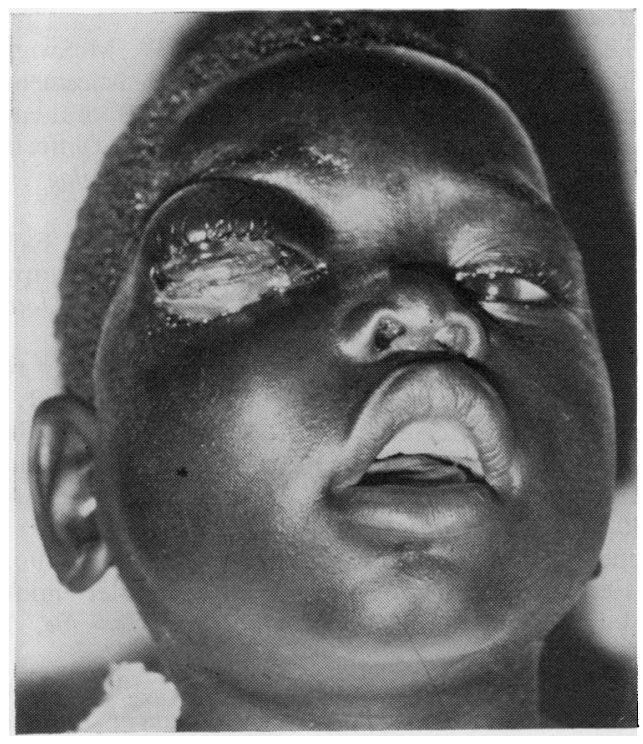

Fig. 7 Burkitt's lymphoma. Photograph by Mr D. P. Burkitt.

EBV occurs early in life, approximately $80 \%$ of children having VCA antibody by the age of 2 years. Patients with Burkitt's lymphoma have been found to have higher levels of antibodies against a wide range of EBV antigens than unaffected children of the same age from the same area (Henle et al., 1971a). In addition, EBV nuclear and membrane antigen (Reedman et al., 1974) and EBV DNA can be detected in the tumours (Zur Hausen and SchulteHolthausen, 1970). These facts, together with the oncogenic potential of EBV demonstrated by experiments in new world primates (Shope et al., 1973), have provided strong circumstantial evidence for EBV playing an aetiological role in the tumour. However, both malaria and EBV infection are almost universal in the childhood population in the lymphoma belt of Africa, and some other cofactor is required to explain the low incidence of tumour. Prospective seroepidemiological studies recently reported (de Thé et al., 1978) show that unusually high titres of antibody to VCA are present for some time before the onset of tumour, suggesting that a very early or very heavy virus infection is an additional risk factor in tumour development.

The evidence linking EBV with nasopharyngeal carcinoma is very similar to that linking the virus with Burkitt's lymphoma, even though the two tumours differ fundamentally in clinical, pathological, and epidemiological behaviour. Nasopharyngeal carcinoma has a high incidence in certain south-east Asian population groups, and genetic factors are of special significance in the development of the tumour (Simons et al., 1975). As in patients with Burkitt's lymphoma, patients with nasopharyngeal carcinoma have higher titres of EBV antibody than normal individuals or individuals with other nasopharyngeal tumours living in the same area (Henle et al., 1970). There are, however, two unique features of EBV infection in nasopharyngeal carcinoma. The tumour cells in which EBV nuclear antigen and EBV DNA can be demonstrated are epithelial in nature (Wolf et al., 1973). This is the only situation in which the presence of EBV genetic material has been confirmed in cells other than B lymphocytes. The second unique feature of EBV infection in patients with this tumour is the very high level of IgA antibody to capsid antigen that can be demonstrated in sera and saliva of these patients both before and after the onset of tumour symptoms (Henle and Henle, 1976; Ho et al., 1978).

\section{Conclusions}

In our introductory remarks, reference was made to the remarkably successful parasitism of herpesviruses. This review of the pathogenic potential of human herpesviruses has emphasised the importance of immune defence mechanisms in achieving and maintaining this balanced host-virus relationship. Subtle deficiencies, particularly in the cellular immune response, may alter the course of any herpesvirus infection from a subclinical and totally unremarkable experience to a serious, invasive, even life-threatening condition. Keeping the herpes hazard at bay demands from clinical pathologists continued ingenuity and effort directed towards safe prevention, early diagnosis, and successful treatment.

\section{References}

Adams, J. H., and Jennett, W. B. (1967). Acute necrotizing encephalitis: a problem in diagnosis. Journal of Neurology, Neurosurgery and Psychiatry, 30, 248-260.

Adamson, H. G. (1909). Herpes febrilis attacking the fingers. British Journal of Dermatology, 21, 323-324.

Albrecht, T., and Rapp, F. (1973). Malignant transformation of hamster embryo fibroblasts following exposure to UV-irradiated HCMV. Virology, 55, 53-61.

Anuras, S., and Summers, R. (1976). Fulminant herpes simplex hepatitis in an adult: Report of a case in a renal transplant recipient. Gastroenterology, 70, 425-428.

Appelbaum, E., Kreps, S. I., and Sunshine, A. (1962). Herpes zoster encephalitis. American Journal of Medicine, 32, 25-31.

Appelbaum, E., Rachelson, M. H., and Dolgopol, V. B. (19.53). Varicella encephalitis. American Journal of Medicine, 15, 223-230.

Arnold, A. G., Lawrence, D. S., and Corbitt, G. (1978). Cytomegalovirus infection and the Guillain-Barré syndrome. Postgraduate Medical Journal, 54, 112-114. Asano, Y., Nakayama, H., Yazaki, T., Ito, S., Isomura, 
S., and Takahashi, M. (1977a). Protective efficacy of vaccination in children in four episodes of natural varicella and zoster in the ward. Pediatrics, 59, 8-12.

Asano, Y., Nakayama, H., Yazaki, T., Kato, R., Hirose, S., Tsuzuki, K., Ito, S., Isomura, S., and Takahashi, M. (1977b). Protection against varicella in family contacts by immediate inoculation with live varicella vaccine. Pediatrics, 59, 3-7.

Aston, D. L., Cohen, A., and Spindler, M. A. (1972). Herpesvirus hominis infection in patients with myeloproliferative and lymphoproliferative disorders. British Medical Journal, 4, 462-465.

Astruc, J. (1754). A Treatise of Venereal Diseases, Pt. 1, Book 3, Ch. 8, p. 365. W. Innys, London. Quoted in Hutfield, D. C. (1966). British Journal of Venereal Diseases, 42, 263-268.

Bamji, A., and Salisbury, R. (1978). Cytomegalovirus and vasculitis. British Medical Journal, 1, 623-624.

Banatvala, J. E., Best, J. M., and Waller, D. K. (1972). Epstein-Barr virus IgM in infectious mononucleosis, Burkitt lymphoma and nasopharyngeal carcinoma. Lancet, 1, 1205-1208.

Bar, R. S., Delor, C. J., Clausen, K. P., Hurtubise, P., Henle, W., and Hewetson, J. F. (1974). Fatal infectious mononucleosis in a family. New England Journal of Medicine, 290, 363-367.

Baringer, J. R. (1974). Recovery of herpes simplex virus from human sacral ganglions. New England Journal of Medicine, 291, 828-830.

Baringer, J. R., and Swoveland, P. (1973). Recovery of herpes-simplex virus from human trigeminal ganglions. New England Journal of Medicine, 288, 648-650.

Bastian, F. O., Rabson, A. S., Yee, C. L., and Tralka, T. S. (1972). Herpesvirus hominis: Isolation from human trigeminal ganglion. Science, 178, 306-307.

Becker, W., Naudé, W. du T., Kipps, A., and McKenzie, D. (1963). Virus studies in disseminated herpes simplex infections: association with malnutrition in children. South African Medical Journal, 37, 74-76.

Bernstein, M. T., and Stewart, J. A. (1971). Indirect hemagglutination test for detection of antibodies to cytomegalovirus. Applied Microbiology, 21, 84-89.

Betts, R. F., Freeman, R. B., Douglas, R. G., Jr., and Talley, T. E. (1977). Clinical manifestations of renal allograft derived primary cytomegalovirus infection. American Journal of Diseases of Children, 131, 759-763.

Betts, R. F., Freeman, R. B., Douglas, R. G., Jr., Talley, T. E., and Rundell, B. (1975). Transmission of cytomegalovirus infection with renal allograft. Kidney International, 8, 385-392.

Beynesh-Melnick, M. (1969). 'Cytomegalovirus', p. 701. In Diagnostic Procedures for Viral and Rickettsial Infections, 4th edition. Edited by E. H. Lennette and Nathalie J. Schmidt. American Public Health Association Incorporated, New York.

Biggar, R. J., Henle, W., Fleisher, G., Böcker, J., Lennette, E. T., and Henle, G. (1978). Primary Epstein-Barr virus infections in African infants. 1. Decline of maternal antibodies and time of infection. International Journal of Cancer, 22, 239-243.

Blair, A. W., Jamieson, W. M., and Smith, G. H. (1965). Complications and death in chickenpox. British
Medical Journal, 2, 981-983.

Blake, J. M., Edwards, J. M. B., Fletcher, W., McSwiggan, D. A., and Pereira, M. S. (1976). Measurement of heterophil antibody and antibodies to EB viral capsid antigen IgG and IgM in suspected cases of infectious mononucleosis. Journal of Clinical Pathology, 29, 841-847.

Boston Interhospital Virus Study Group (1975). Failure of high dose 5-iodo-2'deoxyuridine in the therapy of herpes simplex virus encephalitis. New England Journal of Medicine, 292, 599-603.

British Medical Journal (1979). Shingles: a belt of roses from Hell (Editorial). British Medical Journal, 1, 5.

Brunell, P. A., Gershon, A. A., Hughes, W. T., Riley, H. D., Jr., and Smith, J. (1972). Prevention of varicella in high risk children: a collaborative study. Pediatrics, 50, 718-722.

Brunell, P. A., Ross, A., Miller, L. H., and Kuo, B. (1969). Prevention of varicella by zoster immune globulin. New England Journal of Medicine, 280, 1191-1194.

Burnet, F. M., and Williams, S. W. (1939). Herpes simplex: a new point of view. Medical Journal of Australia, 1, 637-642.

Carstairs, L. S., and Emond, R. T. D. (1963). Chickenpox virus pneumonia. Proceedings of the Royal Society of Medicine, 56, 267-273.

Chan, S. H., de Thé, G., and Goh, E. H. (1977). Prospective study of Epstein-Barr virus antibody titres and survival in patients with nasopharyngeal carcinoma (Letter). Lancet, 1, 948-949.

Chang, R. S., Lewis, J. P., and Abildgaard, C. F. (1973). Prevalence of oropharyngeal excretors of leukocytetransforming agents among a human population. New England Journal of Medicine, 289, 1325-1329.

Chang, R. S., Lewis, J. P., Reynolds, R. D., Sullivan, M. J., and Neuman, J. (1978). Oropharyngeal excretion of Epstein-Barr virus by patients with lymphoproliferative disorders and by recipients of renal homografts. Annals of Internal Medicine, 88, 34-40.

Charkes, N. D. (1961). Purpuric chickenpox: report of a case, review of the literature, and classification by clinical features. Annals of Internal Medicine, 54, 745-759.

Chawla, H. B., Ford, M. J., Munro, J. F., Scorgie, R. E., and Watson, A. R. (1976). Ocular involvement in cytomegalovirus infection in a previously healthy adult. British Medical Journal, 2, 281-282.

Cheatham, W. J., Weller, T. H., Dolan, T. F., Jr., and Dower, J. C. (1956). Varicella: report of two fatal cases with necropsy, virus isolation and serologic studies. American Journal of Pathology, 32, 1015-1035.

Chiba, S., Striker, R. L., Jr., and Beynesh-Melnick, M. (1972). Microculture plaque assay for human and simian cytomegaloviruses. Applied Microbiology, 23, 780-783.

Ch'ien, L. T., Cannon, N. J., Whitley, R. J., Diethelm, A. G., Dismukes, W. E., Scott, C. W., Buchanan, R. A., and Alford, C. A., Jr. (1974). Effect of adenine arabinoside on cytomegalovirus infection. Journal of Infectious Diseases, 130, 32-39.

Cooper, H. S., Raffensperger, E. C., Jonas, L., and Fitts, 
W. T., Jr. (1977). Cytomegalovirus inclusions in patients with ulcerative colitis and toxic dilatation requiring colonic resection. Gastroenterology, 72, 1253-1256.

Courtney, R. J., and Powell, K. L. (1975). Immunological and biochemical characterization of polypeptides induced by herpes simplex virus types 1 and 2 . In Oncogenesis and Herpesviruses, II, pt. 2, pp. 63-67. Edited by G. de Thé, M. A. Epstein, and H. zur Hausen. IARC, Lyons.

Craighead, J. F., Hanshaw, J. B., and Carpenter, C. B. (1967). Cytomegalovirus infection after renal allotransplantation. Journal of the American Medical Association, 201, 725-728.

Crawford, D. H., Epstein, M. A., Achong, B. G., Finerty, S., Newman, J., Liversedge, S., Tedder, R. S., and Stewart, J. W. (1979). Virological and immunological studies on a fatal case of infectious mononucleosis. Journal of Infection, 1, 37-48.

Crawford, D. H., Rickinson, A. B., Finerty, S., and Epstein, M. A. (1978). Epstein-Barr (EB) virus genome containing EB nuclear antigen-negative B-lymphocyte populations in acute infectious mononucleosis. Journal of General Virology, 38, 449-460.

Crosby, D. L., Jones, J. H., and Sussman, M. (1969). Herpetic naso-oral ulcers after renal transplantation (Letter). Lancet, 2, 1191.

Dalldorf, G., Linsell, C. A., Barnhart, F. E., and Martyn, R. (1964). An epidemiological approach to the lymphomas of African children and Burkitt's sarcoma of the jaws. Perspectives in Biology and Medicine, 7, 435-449.

de Thé, G., Geser, A., Day, N. E., Tukei, P. M., Williams, E. H., Beri, D. P., Smith, P. G., Dean, A. G., Bornkamm, G. W., Feorino, P., and Henle, W. (1978). Epidemiological evidence for causal relationship between Epstein-Barr virus and Burkitt's lymphoma from Ugandan prospective study. Nature, 274, 756-761.

Diderholm, H., Stenram, U., Tegner, K. B., and Willén, R. (1969). Herpes simplex hepatitis in an adult. Acta Medica Scandinavica, 186, 151-155.

Diosi, P., Moldovan, E., and Tomescu, N. (1969). Latent cytomegalovirus infection in blood donors. British Medical Journal, 4, 660-662.

Douglas, R. G., Jr., and Couch, R. B. (1970). A prospective study of chronic herpes simplex virus infection and recurrent herpes labialis in humans. Journal of Immunology, 104, 289-295.

Dowling, J. N., Saslow, A. R., Armstrong, J. A., and Ho, M. (1976). Cytomegalovirus infection in patients receiving immunosuppressive therapy for rheumatologic disorders. Journal of, Infectious Diseases, 133, 399-408.

Duff, R., and Rapp, F. (1971). Oncogenic transformation of hamster cells after exposure to herpes simplex virus type 2. Nature New Biology, 233, 48-50.

Duvall, C. P., Casazza, A. R., Grimley, P. M., Carbone, P. P., and Rowe, W. P. (1966). Recovery of cytomegalovirus from adults with neoplastic disease. Annals of Internal Medicine, 64, 531-541.

Ehrlich, R. M., Turner, J. A. P., and Clarke, M. (1958). Neonatal varicella: A case report with isolation of the virus. Journal of Pediatrics, 53, 139-147.

Elek, S. D., and Stern, H. (1974). Development of a vaccine against mental retardation caused by cytomegalovirus infection in utero. Lancet, 1, 1-5.

Emödi, G., O'Reilly, R., Müller, A., Everson, L. K., Binswanger, U., and Just, M. (1976). Effect of human exogenous leukocyte interferon in cytomegalovirus infections. Journal of Infectious Diseases, 133, Supplement A199-A204.

Epstein, M. A., and Achong, B. G. (1977). Recent progress in Epstein-Barr virus research. Annual Review of Microbiology, 31, 421-445.

Epstein, M. A., Achong, B. G., and Barr, Y. M. (1964). Virus particles in cultured lymphoblasts from Burkitt's lymphoma (Letter). Lancet, 1, 702-703.

Ernberg, I., Masucci, G., and Klein, G. (1976). Persistence of Epstein-Barr viral nuclear antigen (EBNA) in cells entering the EB viral cycle. International Journal of Cancer, 17, 197-203

Evans, A. S., Niederman, J. C., and McCollum, R. W. (1968). Seroepidemiologic studies of infectious mononucleosis with EB virus. New England Journal of Medicine, 279, 1121-1127.

Ey, R. C., Hughes, W. F., Holmes, A. W., and Deinhardt, F. (1964). Clinical and laboratory evaluation of idoxuridine (IDU) therapy in herpes simplex keratitis. Archives of Ophthalmology, 71, 325-331.

Faden, H. S., Bybee, B. L., Overall, J. C., Jr., and Lahey, M. E. (1977). Disseminated herpesvirus hominis infection in a child with acute leukemia. Journal of Pediatrics, 90, 951-953.

Feldman, S., Hughes, W. T., and Kim, H. Y. (1973). Herpes zoster in children with cancer. American Journal of Diseases of Children, 126, 178-184.

Fiala, M., Payne, J. E., Berne, T. V., Moore, T. C., Henle, W., Montgomerie, J. Z., Chatterjee, S. N., and Guze, L. B. (1975). Epidemiology of cytomegalovirus infection after transplantation and immunosuppression. Journal of Infectious Diseases, 132, 421-433.

Finch, S. C. (1969). Clinical symptoms and signs of infectious mononucleosis. In Infectious Mononucleosis, edited by R. L. Carter and H. G. Penman, P19-46. Blackwell Scientific Publications, Oxford and Edinburgh.

Finkel, K. C. (1961). Mortality from varicella in children receiving adrenocorticosteroids and adrenocorticotropin. Pediatrics, 28, 436-441.

Flewett, T. H., Parker, R. G. F., and Philip, W. M. (1969). Acute hepatitis due to herpes simplex virus in an adult. Journal of Clinical Pathology, 22, 60-66.

Foley, F. D., Greenawald, K. A., Nash, G., and Pruitt, B. A., Jr. (1970). Herpes infection in burned patients. New England Journal of Medicine, 282, 652-656.

Foster, J. B. (1969). Facial pain. British Medical Journal, 4, 667-669.

Francis, T. I., Osuntokun, B. O., and Kemp, G. E. (1972). Fulminant hepatitis due to herpesvirus hominis in an adult human. American Journal of Gastroenterology, 57, 329-332.

Freud, P. (1958). Congenital varicella. AMA Journal of Diseases of Children, 96, 730-733.

Gerber, P., Nkrumah, F. K., Pritchett, R., and Kieff, E. 
(1976). Comparative studies of Epstein-Barr virus strains from Ghana and the United States. International Journal of Cancer, 17, 71-81.

Gerber, P., Nonoyama, M., Lucas, S., Perlin, E., and Goldstein, L. I. (1972). Oral excretion of Epstein-Barr virus by healthy subjects and patients with infectious mononucleosis. Lancet, 2, 988-989.

Gerber, P., Walsh, J. H., Rosenblum, E. N., and Purcell, R. H. (1969). Association of EB virus with the postperfusion syndrome. Lancet, 1, 593-595.

Gerna, G., Cereda, P. M., Cattaneo, E., Achilli, G., and Revello, M. G. (1978). Immunoglobulin $G$ to virusspecific early antigens in congential, primary, and reactivated human cytomegalovirus infections. Infection and Immunity, 22, 833-841.

Gershon, A. A. (1975). Varicella in mother and infant: problems old and new. In Infections of the Fetus and the Newborn Infant, edited by S. Krugman and A. A. Gershon. (Progress in Clinical and Biological Research, 3) pp. 79-95. Liss, New York.

Glaser, R., and Rapp, F. (1975). Biological properties of the Epstein-Barr virus and its possible role in human malignancy. Progress in Medical Virology, 21, 43-57.

Goffinet, D. R., Glatstein, E. J., and Merigan, T. C. (1972). Herpes zoster-varicella infection and lymphoma. Annals of Internal Medicine, 76, 235-254.

Goodpasture, E. W. (1929). Herpetic infection, with especial reference to involvement of the nervous system. Medicine, 8, 223-243.

Gordon, J. E. (1962). Chickenpox: an epidemiological review. American Journal of the Medical Sciences, 244, 362-389.

Grist, N. R., Bell, E. J., Follett, E. A. C., and Urquhart, G. E. D. (1979). Diagnostic Methods in Clinical Virology, 3rd edition, p. 161. Blackwell Scientific Publications, Oxford.

Grose, C., Henle, W., and Horwitz, M. S. (1977). Primary Epstein-Barr virus infection in a renal transplant recipient. Southern Medical Journal, 70, 1276-1278.

Gupta, S. K., Helal, B. H., and Kiely, P. (1969). The prognosis in zoster paralysis. Journal of Bone and Joint Surgery, 51B, 593-603.

Gyde, O. H. B., and Beales, D. L. (1970). Gangrene of digits after chickenpox. British Medical Journal, 4, 284.

Haggerty, R. J., and Eley, R. C. (1956). Varicella and cortisone (Letter). Pediatrics, 18, 160-162.

Hanshaw, J. B. (1971). Congenital cytomegalovirus infection: a fifteen years perspective. Journal of Infectious Diseases, 123, 555-561.

Hanshaw, J. B., and Dudgeon, J. A. (1978). Viral Diseases of the Fetus and Newborn, pp. 199-204. Saunders, Philadelphia and London.

Hanshaw, J. B., Scheiner, A. P., Moxley, A. W., Gaev, L., Abel, V., and Scheiner, B. (1976). School failure and deafness after 'silent' congenital cytomegalovirus infection. New England Journal of Medicine, 295, 468-470.

Hanshaw, J. B., Steinfeld, H. J., and White, C. J. (1968). Fluorescent-antibody test for cytomegalovirus macroglobulin. New England Journal of Medicine, 279, 566-570.

Hass, G. M. (1935). Hepato-adrenal necrosis with intra- nuclear inclusion bodies. American Journal of Pathology, 11, 127-142.

Hattori, A., Ihara, T., Iwasa, T., Kamiya, H., Sakurai, M., and Izawa, T. (1976). Use of live varicella vaccine in children with acute leukaemia or other malignancies (Letter). Lancet, 2, 210.

Henle, G., and Henle, W. (1970). Observations on childhood infections with the Epstein-Barr virus. Journal of Infectious Diseases, 121, 303-310.

Henle, G., and Henle, W. (1976). Epstein-Barr virusspecific IgA serum antibodies as an outstanding feature of nasopharyngeal carcinoma. International Journal of Cancer, 17, 1-7.

Henle, G., Henle, W., and Horwitz, C. A. (1974b). Antibodies to Epstein-Barr virus-associated nuclear antigen in infectious mononucleosis. Journal of Infectious Diseases, 130, 231-239.

Henle, G., Henle, W., Klein, G., Gunven, P., Clifford, P., Morrow, R. H., and Ziegler, J. L. (1971a). Antibodies to early Epstein-Barr virus-induced antigens in Burkitt's lymphoma. Journal of the National Cancer Institute, 46, 861-871.

Henle, W., Henle, G., Hewetson, J., Rocchi, G., and Leikola, J. (1974a). Failure to detect heterophile antigens in Epstein-Barr virus-infected cells and to demonstrate interaction of heterophile antibodies with Epstein-Barr virus. Clinical and Experimental Immunology, 17, 281-286.

Henle, W., Henle, G., Ho, H. C., Burtin, P., Cachin, Y., Clifford, P., de Schryver, A., de Thé, G., Diehl, V., and Klein, G. (1970). Antibodies to Epstein-Barr virus in nasopharyngeal carcinoma, other head and neck neoplasms and control groups. Journal of the National Cancer Institute, 44, 225-231.

Henle, W., Henle, G., Niederman, J. C., Klemola, E., and Haltia, K. (1971b). Antibodies to early antigens induced by Epstein-Barr virus in infectious mononucleosis. Journal of Infectious Diseases, 124, 58-67.

Hewetson, J. F., Rocchi, G., Henle, W., and Henle, G. (1973). Neutralizing antibodies to Epstein-Barr virus in healthy populations and patients with infectious mononucleosis. Journal of Infectious Diseases, 128, 283-289.

Ho, H. C., Kwan, H. C., Mun, H. Ng, and de Thé, G. (1978). Serum IgA antibodies to Epstein-Barr virus capsid antigen preceding symptoms of nasopharyngeal carcinoma (Letter). Lancet, 1, 436.

Ho, M., Suwansirikul, S., Dowling, J. N., Youngblood, L. A., and Armstrong, J. A. (1975). The transplanted kidney as a source of cytomegalovirus infection. New England Journal of Medicine, 293, 1109-1112.

Hope Simpson, R. E. (1954). Studies on shingles. Is the virus ordinary chickenpox virus? Lancet, 2, 1299-1302.

Hope Simpson, R. E. (1965). The nature of herpes zoster: a long-term study and a new hypothesis. Proceedings of the Royal Society of Medicine, 58, 9-20.

Howiler, W., and Goldberg, H. I. (1976). Gastroesophageal involvement in herpes simplex. Gastroenterology, 70, 775-778.

Huang, E. S., and Roche, J. K. (1978). Cytomegalovirus D.N.A. and adenocarcinoma of the colon: evidence for latent viral infection. Lancet, 1, 957-960. 
Hutfield, D. C. (1967). Isolation studies with genital strains of herpes simplex virus. Acta dermatovenereologica, 47, 118-122.

Jellinek, E. H., and Tulloch, W. S. (1976). Herpes zoster with dysfunction of bladder and anus. Lancet, 2, 1219-1222.

Jondal, M., and Klein, G. (1973). Surface markers on human B and T lymphocytes. II. Presence of EpsteinBarr receptors on B lymphocytes. Journal of Experimental Medicine, 138, 1365-1378.

Jones, B. R. (1958). The clinical features of viral keratitis and a concept of their pathogenesis. Proceedings of the Royal Society of Medicine, 51, 917-924.

Jones, B. R., Coster, D. J., Falcon, M. G., and Cantell, K. (1976). Topical therapy of ulcerative herpetic keratitis with human interferon. Lancet, 2, 128.

Jones, B. R., Coster, D. J., Fison, P. N., Thompson, G. M., Cobo, L. M., and Falcon, M. G. (1979). Efficacy of acycloguanosine (Wellcome $248 \mathrm{u}$ ) against herpes-simplex corneal ulcers. Lancet, 1, 243-247.

Jordan, M. C., Rousseau, W. E., Stewart, J. A., Noble, G. R., and Chin, T. D. Y. (1973). Spontaneous cytomegalovirus mononucleosis: clinical and laboratory observations in nine cases. Annals of Internal Medicine, 79, 153-160.

Juel-Jensen, B. E. (1970). Severe generalized primary herpes treated with cytarabine. British Medical Journal, 2, 154-155.

Juel-Jensen, B. E., and MacCallum, F. O. (1972). Herpes Simplex, Varicella and Zoster, pp. 117-187. Heinemann, London.

Juel-Jensen, B. E., and MacCallum, F. O. (1974). Idoxuridine in herpes zoster (Letter). British Medical Journal, 3, 41.

Juel-Jensen, B. E., MacCallum, F. O., MacKenzie, A. M. R., and Pike, M. C. (1970). Treatment of zoster with idoxuridine in dimethylsulphoxide: results of two double-blind controlled trials. British Medical Journal, 4, 776-780.

Kääriänen, L., Klemola, E., and Paloheimo, J. (1966). Rise of cytomegalovirus antibodies in an infectiousmononucleosis-like syndrome after transfusion. British Medical Journal, 1, 1270-1272.

Kano, K., Fjelde, A., and Milgrom, F. (1977). PaulBunnell antigen in lymphoma and leukemia spleens. Journal of Immunology, 119, 945-949.

Kantor, G. L., Goldberg, L. S., Johnson, B. L., Jr., Derechin, M. M., and Barnett, E. V. (1970). Immunologic abnormalities induced by postperfusion cytomegalovirus infection. Annals of Internal Medicine, 73, 553-558.

Kaposi, M. (1895). Pathology and Treatment of Diseases of the Skin, pp. 346-347. Ballière, Tindall and Cox, London.

Keller, R., Peitchel, R., Goldman, J. N., and Goldman, M. (1976). An IgG-Fc receptor induced in cytomegalovirus-infected human fibroblasts. Journal of Immunology, 116, 772-777.

Kettering, J. D., Schmidt, N. J., Gallo, D., and Lennette, E. H. (1977a). Anti-complement immunofluorescence test for antibody to human cytomegalovirus. Journal of Clinical Microbiology, 6, 627-632.
Kettering, J. D., Schmidt, N. J., and Lennette, E. H. (1977b). Improved glycine-extracted complementfixing antigen for human CMV. Journal of Clinical Microbiology, 6, 647-649.

Kieff, E., Hoyer, B., Bachenheimer, S., and Roizman, B. (1972). Genetic relatedness of type 1 and type 2 herpes simplex viruses. Journal of Virology, 9, 738-745.

Kipping, R. H., and Downie, A. W. (1948). Generalized infection with the virus of herpes simplex. British Medical Journal, 1, 247-249.

Kipps, A., Becker, W., Wainwright, J., and McKenzie, D. (1967). Fatal disseminated primary herpesvirus infection in children. Epidemiology based on 93 nonfatal cases. South African Medical Journal, 41, 647-651.

Klein, G. (1975). Immunological surveillance against neoplasia. Harvey Lectures, 69 (1973-74), 71-102.

Klein, G., Clements, G., Zeuthen, J., and Westman, A. (1976a). Somatic cell hybrids between human lymphoma lines. II. Spontaneous and induced patterns of Epstein-Barr (EBV) cycle. International Journal of Cancer, 17, 715-724.

Klein, G., Svedmyr, E., Jondal, M., and Persson, P. O. (1976b). EBV-determined nuclear antigen (EBNA)Positive cells in the peripheral blood of infectious mononucleosis patients. International Journal of Cancer, 17, 21-26.

Klemola, E., and Kääriäinen, L. (1965). Cytomegalovirus as a possible cause of a disease resembling infectious mononucleosis. British Medical Journal, 2, 1099-1102.

Knowles, W. A. (1976). In-vitro cultivation of human cytomegalovirus in thyroid epithelial cells. Archives of Virology, 50, 119-124.

Knyvett, A. F. (1966). The pulmonary lesions of chickenpox. Quarterly Journal of Medicine, 35, 313-323.

Koranda, F. C., Dehmel, E. M., Kahn, G., and Penn, I. (1974). Cutaneous complications in immuno-suppressed renal homograft recipients. Journal of the American Medical Association, 229, 419-424.

Krech, U. (1973). Complement-fixing antibodies against cytomegalovirus in different parts of the world. Bulletin of the World Health Organisation, 49, 103-106.

Laforet, E. G., and Lynch, C. L., Jr. (1947). Multiple congenital defects following maternal varicella: report of a case. New England Journal of Medicine, 236, 534-537.

Lamb, S. G., and Stern, H. (1966). Cytomegalovirus mononucleosis with jaundice as presenting sign. Lancet, 2, 1003-1006.

Lancet (1973). Immunopathology of infectious mononucleosis (Editorial). Lancet, 2, 712-714.

Lang, D. J., Montagnier, L., and Latarjet, R. (1974). Growth in agarose of human cells infected with cytomegalovirus. Journal of Virology, 14, 327-332.

Lang, D. J., and Noren, B. (1968). Cytomegaloviremia following congenital infection. Journal of Pediatrics, 73, 812-819.

Lee, J. C., and Fortuny, I. E. (1972). Adult herpes simplex hepatitis. Human Pathology, 3, 277-281.

Legendre, F. L. (1853). Mémoire sur l'herpès de la vulve. Archives Générales de Médicine, 5th series, 2, 171-204.

Lewis, G. W. (1958). Zoster sine herpete. British Medical Journal, 2, 418-421. 
Linnemann, C. C., Buchman, T. G., Light, I. J., Ballard, J. L., and Roizman, B. (1978). Transmission of herpes simplex virus type 1 in a nursery for the newborn: identification of viral isolates by DNA 'fingerprinting'. Lancet, 1, 964-966.

Lonsdale, D. M., Brown, S. M., Subak-Sharpe, J. H., Warren, K. G., and Koprowski, H. (1979). The polypeptide and the DNA restriction enzyme profiles of spontaneous isolates of herpes simplex virus type 1 from explants of human trigeminal, superior cervical and vagus ganglia. Journal of General Virology, 43, 151-171.

Lopez, C., Simmons, R. L., Mauer, S. M., Najarian, J. S., Good, R. A., and Gentry, S. (1974). Association of renal allograft rejection with virus infections. American Journal of Medicine, 56, 280-289.

Lowenthal, R. M., McLauchlan, S. L., and Tyrrell, D. A. J. (1973). Human antigen for the Paul-Bunnell antibody. Nature (New Biology) London, 244, 109-111.

Lynch, F. W. (1945). Kaposi's varicelliform eruption: extensive herpes simplex as a complication of eczema. Archives of Dermatology and Syphilology, 51, 129-137.

MacDonald, H., and Tobin, J. O'H. (1978). Congenital cytomegalovirus infection: a collaborative study on epidemiological, clinical and laboratory findings. Developmental Medicine and Child Neurology, 20, 471-482.

Macnab, J. C. M. (1974). Transformation of rat embryo cells by temperature-sensitive mutants of herpes simplex virus. Journal of General Virology, 24, 143-153.

May, A. G., Betts, R. F., Freeman, R. B., and Andrus, C. H. (1978). An analysis of cytomegalovirus infection and HLA antigen matching on the outcome of renal transplantation. Annals of Surgery, 187, 110-117.

Melish, M. E., and Hanshaw, J. B. (1973). Congenital cytomegalovirus infection. Developmental progress of infants detected by routine screening. American Journal of Diseases of Children, 126, 190-194.

Merigan, T. C., Rand, K. H., Pollard, R. B., Abdallah, P. S., Jordan, G. W., and Fried, R. P. (1978). Human leukocyte interferon for the treatment of herpes zoster in patients with cancer. New England Journal of Medicine, 298, 981-987.

Merselis, J. G., Jr., Kaye, D., and Hook, E. W. (1964). Disseminated herpes zoster. Archives of Internal Medicine, 113, 679-686.

Meyer, R., Brown, H P., and Harrison, J. H. (1959). Herpes zoster involving the urinary bladder. New England Journal of Medicine, 260, 1062-1065.

Meyers, J. D., Spencer, H. C., Jr., Watts, J. C., Gregg, M. B., Stewart, J. A., Troupin, R. H., and Thomas, E. D. (1975). Cytomegalovirus pneumonia after human marrow transplantation. Annals of Internal Medicine, 82, 181-188.

Miller, G. (1975). Epstein-Barr herpesvirus and infectious mononucleosis. Progress in Medical Virology, 20, 84-112.

Miller, G., Niederman, J. C., and Andrews, L. (1973). Prolonged oropharyngeal excretion of Epstein-Barr virus after infectious mononucleosis. New England Journal of Medicine, 288, 229-232.

Miller, H. G., Stanton, J. B., and Gibbons, J. L. (1956).
Para-infectious encephalomyelitis and related syndromes. Quarterly Journal of Medicine, 25, 427-505 (see p. 446 onwards).

Mintz, L. (1976). Herpes virus infections in the postnatal period. In Viral Infections: a Clinical Approach. Edited by W. Lawrence Drew, pp. 135-187. Davis, Philadelphia.

Montgomerie, J. Z., Becroft, D. M. O., Croxson, M. C., Doak, P. B., and North, J. D. K. (1969). Herpessimplex-virus infection after renal transplantation. Lancet, 2, 867-871.

Moss, D. J., Rickinson, A. B., and Pope, J. H. (1978). Long-term T-cell-mediated immunity to Epstein-Barr virus in man. I. Complete regression of virus-induced transformation in cultures of seropositive donor leukocytes. International Journal of Cancer, 22, 662-668.

Muir, R. (1976). Muir's Textbook of Pathology, 10th edition. Edited by J. R. Anderson, p. 696. Arnold, London.

Mukundan, P., Jadhav, M., and John, T. J. (1977). Prevalence of cytomegalovirus antibody in young children in Vellore. Indian Journal of Medical Research, 65, 589-592.

Nahmias, A. J., Josey, W. E., and Naib, Z. M. (1967). Neonatal herpes simplex infection: Role of genital infection in mother as the source of virus in the newborn. Journal of the American Medical Association, 199, 164-168.

Naib, Z. M. (1966). Exfoliative cytology of viral cervicovaginitis. Acta Cytologica, 10, 126-129.

Naraqi, S., Jackson, G. G., and Jonasson, O. M. (1976). Viremia with herpes simplex type 1 in adults. Four nonfatal cases, one with features of chickenpox. Annals of Internal Medicine, 85, 165-169.

Naraqi, S., Jackson, G. G., Jonasson, O. M., and Rubenis, M. (1978). Search for latent cytomegalovirus in renal allografts. Infection and Immunity, 19, 699-703.

Newman, C. G. H. (1965). Perinatal varicella. Lancet, 2, 1159-1161.

Nichols, W. W. (1957). Experience with chickenpox in patients with hematologic disease receiving cortisone. American Journal of Diseases of Children, 94, 219-223.

Niederman, J. C., Evans, A. S., Subrahmanyan, L., and McCollum, R. W. (1970). Prevalence, incidence and persistence of EB virus antibody in young adults. New England Journal of Medicine, 282, 361-365.

Nikoskelainen, J., Leikola, J., and Klemola, E. (1974). IgM antibodies specific for Epstein-Barr virus in infectious mononucleosis without heterophile antibodies. British Medical Journal, 4, 72-75.

Nilsson, K. (1971). High-frequency establishment of human immunoglobulin-producing lymphoblastoid lines from normal and malignant lymphoid tissue and peripheral blood. International Journal of Cancer, 8, 432-442.

Nonoyama, M., and Pagano, J. S. (1972). Separation of Epstein-Barr virus DNA from large chromosome DNA in non-virus-producing cells. Nature (London) New Biology, 238, 169-171.

Norn, M. S. (1970). Dendritic (herpetic) keratitis 1. Incidence, seasonal variations, recurrence rate, visual impairment, therapy. Acta Ophthalmologica, 48, 91-107. 
Olding, L. B., Jensen, F. C., and Oldstone, M. B. A. (1975). Pathogenesis of cytomegalovirus infection. I. Activation of virus from bone marrow-derived lymphocytes by in vitro allogenic reaction. Journal of Experimental Medicine, 141, 561-572.

Olson, L. C., Buescher, E. L., Artenstein, M. S., and Parkman, P. D. (1967). Herpesvirus infections of the human central nervous system. New England Journal of Medicine, 277, 1271-1277.

Parker, J. D. J., and Banatvala, J. E. (1967). Herpes genitalis. Clinical and virological studies. British Journal of Venereal Diseases, 43, 212-216.

Pattengale, P. K., Smith, R. W., and Gerber, P. (1973). Selective transformation of B lymphocytes by E.B. virus (Letter). Lancet, 2, 93-94.

Patterson, A., Fox, A. D., Davies, G., Maguire, C., Holmes Sellers, P. J., Wright, P., Rice, N. S. C., Cobb, B., and Jones, B. R. (1963). Controlled studies of IDU in the treatment of herpetic keratitis. Transactions of the Ophthalmological Societies, UK, 83, 583-591.

Pauls, F. P., and Dowdle, W. R. (1967). A serologic study of herpesvirus hominis strains by microneutralization tests. Journal of Immunology, 98, 941-947.

Pereira, M. S., Blake, J. M., and Macrae, A. D. (1969). EB virus antibody at different ages. British Medical Journal, 4, 526-527.

Peterson, P. H., and Black, S. A. B. (1946). Varicella herpeteformis (Letter). British Medical Journal, 1, 762.

Pinkel, D. (1961). Chickenpox and leukaemia. Journal of Pediatrics, 58, 729-737.

Plotkin, S. A., Farquhar, J., and Hornberger, E. (1976). Clinical trials of immunization with the Towne 125 Strain of human cytomegalovirus. Journal of Infectious Diseases, 134, 470-475.

Plummer, G. (1967). Comparative virology of the herpes group. Progress in Medical Virology, 9, 302-340.

Plummer, G. (1973). Cytomegaloviruses of man and animals. Progress in Medical Virology, 15 92-125.

Plummer, G., Waner, J. L., and Bowling, C. P. (1968). Comparative studies of type 1 and type 2 "herpes simplex' viruses. British Journal of Experimental Pathology, 49, 202-208.

Plummer, G., Waner, J. L., Phuangsab, A., and Goodheart, C. R. (1970). Type 1 and type 2 herpes simplex viruses: serological and biological differences. Journal of Virology, 5, 51-59.

Purtilo, D. T., Szymanski, I., Bhawan, J., Yang, J. P. S., Hutt, L. M., Boto, W., DeNicola, L., Maier, R., and Thorley-Lawson, D. (1978). Epstein-Barr virus infections in the $\mathrm{X}$-linked recessive lymphoproliferative syndrome. Lancet, 1, 798-801.

Purtilo, D. T., Yang, J. P. S., Cassel, C. K., Harper, R., Stephenson, S. R., Landing, B. H., and Vawter, G. F. (1975). X-linked recessive progressive combined variable immunodeficiency (Duncan's disease). Lancet, 1, 935-940.

Quilligan, J. J., Jr., and Wilson, J. L. (1951). Fatal herpes simplex infection in a newborn infant. Journal of Laboratory and Clinical Medicine, 38, 742-746.

Rand, K. H., Pollard, R. B., and Merigan, T. C. (1978). Increased pulmonary superinfections in cardiac transplant patients undergoing primary cytomegalovirus infection. New England Journal of Medicine, 298, 951-953.

Rawls, W. E., Gardner, H. L., and Kaufman, R. L. (1970). Antibodies to genital herpesvirus in patients with carcinoma of the cervix. American Journal of Obstetrics and Gynaecology, 107, 710-716.

Reedman, B. M., Klein, G., Pope, J. H., Walters, M. K., Hilgers, J., Singh, S., and Johansson, B. (1974). Epstein-Barr virus-associated complement-fixing and nuclear antigens in Burkitt lymphoma biopsies. International Journal of Cancer, 13, 755-763.

Reynolds, D. W., Stagno, S., Reynolds, R., and Alford, C. A., Jr. (1978). Perinatal cytomegalovirus infection: influence of placentally transferred maternal antibody. Journal of Infectious Diseases, 137, 564-567.

Rickinson, A. B., Crawford, D., and Epstein, M. A. (1977). Inhibition of the in vitro outgrowth of EpsteinBarr virus-transformed lymphocytes by thymusdependent lymphocytes from infectious mononucleosis patients. Clinical and Experimental Immunology, 28, 72-79.

Rifkind, D. (1966). The activation of varicella-zoster virus infections by immunosuppressive therapy. Journal of Laboratory and Clinical Medicine, 68, 463-474.

Ruiz-Palacios, G., Pickering, L. K., VanEys, J., and Conklin, R. (1977). Disseminated herpes simplex with hepatoadrenal necrosis in a child with acute leukemia. Journal of Pediatrics, 91, 757-759.

St. Jeor, S., and Weisser, A. (1977). Persistence of cytomegalovirus in human lymphoblasts and peripheral leukocyte cultures. Infection and Immunity, 15, 402-409.

Sargent, E. N., Carson, M. J., and Reilly, E. D. (1967). Varicella pneumonia: a report of 20 cases with post mortem examination in six. California Medicine, 107, 141-148.

Saslaw, S., Kluck, C., and Prior, J. A. (1960). Varicella bullosa. Journal of the American Medical Association, 173, 1214-1217.

Savage, M. O., Moosa, A., and Gordon, R. R. (1973). Maternal varicella infection as a cause of fetal malformations. Lancet, 1, 352-354.

Schimpff, S., Serpick, A., Stoler, B., Rumack, B., Mellin, H., Joseph, J. M., and Block, J. (1972). Varicellazoster infection in patients with cancer. Annals of Internal Medicine, 76, 241-254.

Schneweis, K. E. (1967). Die Typen 1 und 2 des Herpessimplex-Virus bei verschiedenen Krankheitsbildern. Deutsche medizinische Wochenschrift, 92, 2313-2314.

Seiler, H. E. (1949). A study of herpes zoster particularly in its relationship to chickenpox. Journal of Hygiene, 47, 253-262.

Sheldon, P. J., Papamichail, M., Hemsted, E. H., and Holborow, E. J. (1973). Thymic origin of atypical lymphoid cells in infectious mononucleosis. Lancet, 1, 1153-1155.

Shirodaria, P. V., Fraser, K. B., and Stanford, F. (1973). Secondary fluorescent staining of virus antigens by rheumatoid factor and fluorescein-conjugated antiIgM. Annals of Rheumatic Diseases, 32, 53-57.

Shope, T. C., Dechairo, D., and Miller, G. (1973). Malignant lymphoma in cottontop marmosets after 
inoculation with Epstein-Barr virus. Proceedings of the National Academy of Sciences of the United States of America, 70, 2487-2491.

Shope, T. C., and Miller, G. (1973). Epstein-Barr virus: heterophile responses in squirrel monkeys inoculated with virus-transformed autologous leucytes. Journal of Experimental Medicine, 137, 140-147.

Simons, M. J., Wee, G. B., Chan, S. H., Shanmugaratnam, K., Day, N. E., and de Thé, G. B. (1975). Probable identification of an HL-A second-locus antigen associated with a high risk of nasopharyngeal carcinoma. Lancet, 1, 142-143.

Skare, J., Summers, W. P., and Summers, W. C. (1975). Structure and function of herpesvirus genomes. 1. Comparison of five HSV-1 and two HSV-2 strains by cleavage of their DNA with ECO RI restriction endo nuclease. Journal of Virology, 15, 726-732.

Slatkin, M., and Miller, J. L. (1950). Herpes zoster with facial paralysis. Archives of Dermatology and Syphilology, 61, 358-359.

Smith, I. W., Peutherer, J. F., and MacCallum, F O. (1967). The incidence of herpesvirus hominis antibody in the population. Journal of Hygiene, Cambridge, 65, 395-408.

Smith, I. W., Peutherer, J. F., and Robertson, D. H. H. (1976). Virological studies in genital herpes (Letter). Lancet, 2, 1089-1090.

Smith, M. G. (1956). Propagation in tissue culture of a cytopathogenic virus from human salivary gland virus (S.G.V.) disease. Proceedings of the Society for Experimental Biology and Medicine, 92, 424-430.

Smith, M. G., Lennette, E. H., and Reames, H. R. (1941). Isolation of the virus of herpes simplex and the demonstration of intranuclear inclusions in a case of acute encephalitis. American Journal of Pathology, 17, 55-68.

Spencer, E. S. (1974). Clinical aspects of cytomegalovirus infection in kidney-graft recipients. Scandinavian Journal of Infectious Diseases, 6, 315-323.

Spencer, E. S., and Andersen, H. K. (1970). Clinically evident, non-terminal infections with herpesviruses and the wart virus in immunosuppressed renal allograft recipients. British Medical Journal, 3, 251-254.

Spencer, E. S., and Andersen, H. K. (1972). Antibodies to the Epstein-Barr virus in kidney transplant recipients. Acta Medica Scandinavica, 191, 107-110.

Stagno, S., Reynolds, D. W., Huang, E. S., Thames, S. D., Smith, R. J., and Alford, C. A., Jr. (1977). Congenital cytomegalovirus infection: occurrence in an immune population. New England Journal of Medicine, 296, 1254-1258.

Stagno. S., Reynolds, D. W., and Smith, R. J. (1978). Use of isolated nuclei in the indirect fluorescent-antibody test for human cytomegalovirus infection: comparison with microneutralization, anticomplement, and conventional indirect fluorescent-antibody assays. Journal of Clinical Microbiology, 7, 486-489.

Stagno, S., Reynolds, D. W., Tsiantos, A., Fuccillo, D. A., Long, W., and Alford, C. A., Jr. (1975a). Comparative serial virologic and serologic studies of symptomatic and subclinical congenitally and natally acquired cytomegalovirus infections. Journal of
Infectious Diseases, 132, 568-577.

Stagno, S., Reynolds, D. W., Tsiantos, A., Fuccillo, D. A., Smith, R. J., Tiller, M., and Alford, C. A., Jr. (1975b). Cervical cytomegalovirus excretion in pregnant and nonpregnant women: suppression in early gestation. Journal of Infectious Diseases, 131, 522-527.

Stern, H. (1968). Isolation of cytomegalovirus and clinical manifestations of infection at different ages. British Medical Journal, 1, 665-669.

Stern, H., and Elek, S. D. (1965). The incidence of infection with cytomegalovirus in a normal population: a serological study in Greater London. Journal of Hygiene (London), 63, 79-87.

Stern, H., Elek, S. D., Millar, D. M., and Anderson, H. F. (1959). Herpetic whitlow: a form of cross-infection in hospitals. Lancet, 2, 871-874.

Stern, H., and Tucker, S. M. (1973). Prospective study of cytomegalovirus infection in pregnancy. British Medical Journal, 2, 268-270.

Strauch, B., Siegel, N., Andrews, L.-L., and Miller, G. (1974). Oropharyngeal excretion of Epstein-Barr virus by renal transplant recipients and other patients treated with immunosuppressive drugs. Lancet, 1, 234-237.

Sullivan, J. L., Wallen, W. C., and Johnson, F. L. (1978). Epstein-Barr virus infection following bone-marrow transplantation. International Journal of Cancer, 22, 132-135.

Takahashi, M., Otsuka, T., Okuno, Y., Asano, Y., Yazaki, T., and Isomura, S. (1974). Live vaccine used to prevent the spread of varicella in children in hospital. Lancet, 2, 1288-1290.

Taterka, J. H., and O'Sullivan, M. E. (1943). The motor complications of herpes zoster. Journal of the American Medical Association, 122, 737-739.

Thé, T. H., Klein, G., and Langenhuysen, M. M. A. C. (1974). Antibody reactions to virus-specific early antigens (EA) in patients with cytomegalovirus (CMV) infection. Clinical and Experimental Immunology, 16, $1-12$.

Tiula, E., and Leinikki, P. (1972). Fatal cytomegalovirus infection in a previously healthy boy with myocarditis and consumption coagulopathy as presenting signs. Scandinavian Journal of Infectious Diseases, 4, 57-60.

Tobin, J. O'H., MacDonald,. H., and Brayshay, M. (1975). Cytomegalovirus infection and exchange transfusion (Letter). British Medical Journal, 4, 404.

University Health Physicians and PHLS Laboratories (1971). Infectious mononucleosis and its relationship to EB virus antibody. British Medical Journal, 4, 643-646.

Verbov, J. (1979). Local idoxuridine treatment of herpes simplex and zoster. Journal of Antimicrobial Chemotherapy, 5, 126-128.

Warren, K. G., Brown, S. M., Wroblewska, Z., Gilden, D., Koprowski, H., and Subak-Sharpe, J. H. (1978). Isolation of latent herpes simplex virus from the superior cervical and vagus ganglions of human beings. New England Journal of Medicine, 298, 1068-1069.

Warren, K. G., Devlin, M., Gilden, D. H., Wroblewska, Z., Brown, S. M., Subak-Sharpe, J. H., and Koprowski, H. (1977). Isolation of herpes simplex virus from 
human trigeminal ganglia, including ganglia from one patient with multiple sclerosis. Lancet, 2, 637-639.

Weinstein, L., and Meade, R. H. (1956). Respiratory manifestations of chickenpox. Archives of Internal Medicine, 98, 91-99.

Willcox, R. R. (1968). Necrotic cervicitis due to primary infection with the virus of herpes simplex. British Medical Journal, 1, 610-612.

Whitley, R. J., Soong, S.-J., Dolin, R., Galasso, G. J., Chi'en, L. T., Alford, C. A., and Collaborative Study Group (1977). Adenine arabinoside therapy of biopsyproved herpes simplex encephalitis. New England Journal of Medicine, 297, 289-294.

Willmott, F. E. (1975). Cytomegalovirus in female patients attending a VD clinic. British Journal of Venereal Diseases, 51, 278-280.

Wolf, H., Zur Hausen, H., and Becker, V. (1973). EB viral genomes in epithelial nasopharyngeal carcinoma cells. Nature, London (New Biology), 244, 245-247.
Yeager, A. S. (1974). Transfusion-acquired cytomegalovirus infection in newborn infants. American Journal of Diseases of Children, 128, 478-483.

Yuceoglu, A. M., Berkovich, S., and Minkowitz, S. (1967). Acute glomerulonephritis as a complication of varicella. Journal of the American Medical Association, 202, 879-881.

Zablotney, S. L., Wentworth, B. B., and Alexander, E. R. (1978). Antigenic relatedness of 17 strains of human cytomegalovirus. American Journal of Epidemiology, 107, 336-343.

Zur Hausen, H., and Schulte-Holthausen, H. (1970). Presence of EB virus nucleic acid homology in a 'virus free' line of Burkitt tumour cells. Nature, London, 227, 245-248.

Requests for reprints to: Dr Morag C. Timbury, Bacteriology Department, Royal Infirmary, Glasgow G4 OSF, UK. 